\title{
Simple $b$ Ions Have Cyclic Oxazolone Structures. A Neutralization-Reionization Mass Spectrometric and Computational Study of Oxazolone Radicals
}

\author{
Xiaohong Chen and František Tureček \\ Department of Chemistry, University of Washington, Seattle, Washington, USA
}

The 2-methyloxazol-5-on-2-yl radical (3) and its deuterium labeled analogs were generated in the gas-phase by femtosecond electron-transfer and studied by neutralization-reionization mass spectrometry and quantum chemical calculations. Radical 3 undergoes fast dissociation by ring opening and elimination of $\mathrm{CO}$ and $\mathrm{CH}_{3} \mathrm{CO}$. Loss of hydrogen is less abundant and involves hydrogen atoms from both the ring and side-chain positions. The experimental results are corroborated by the analysis of the potential energy surface of the ground electronic state in 3 using density functional, perturbational, and coupled-cluster theories up to $\operatorname{CCSD}(\mathrm{T})$ and extrapolated to the 6-311 ++ G(3df,2p) basis set. RRKM calculations of radical dissociations gave branching ratios for loss of $\mathrm{CO}$ and $\mathrm{H}$ that were $k_{\mathrm{CO}} / k_{\mathrm{H}}>10$ over an $80-300 \mathrm{~kJ} \mathrm{~mol}^{-1}$ range of internal energies. The driving force for the dissociations of 3 is provided by large Franck-Condon effects on vertical neutralization and possibly from involvement of excited electronic states. Calculations also provided the adiabatic ionization energy of $3, \mathrm{IE}_{\text {adiab }}=5.48$ $\mathrm{eV}$ and vertical recombination energy of cation $3^{+}, \mathrm{RE}_{\mathrm{vert}}=4.70 \mathrm{eV}$. The present results strongly indicate that oxazolone structures can explain fragmentations of $\boldsymbol{b}$-type peptide ions upon electron capture, contrary to previous speculations. (J Am Soc Mass Spectrom 2005, 16, 1941-1956) ( 2005 American Society for Mass Spectrometry

$\mathrm{U}$ pon low-energy collisions, gas-phase peptide ions fragment by peptide bond cleavages that result in the formation of ions containing $\mathrm{N}$ terminal residues ( $\boldsymbol{b}$-series ions) and C-terminal residues ( $y$-ion series) [1]. Based on both ion dissociations and computational studies of ion structure and energetics, it is generally accepted that $y$ ions correspond to truncated protonated peptides [2]. In contrast, there has been some recent disagreement regarding $\boldsymbol{b}$ ions for which as many as four different structures have been proposed, e.g., (1) open chain acylium; (2) protonated oxazolone; (3) protonated diketopiperazine; and (4) immonium ions formed from oxazolone structures [3]. Quantum chemical calculations at various levels of theory (Hartree-Fock, Møller-Plesset, and density functional theory) prefer protonated oxazolone structures for $\boldsymbol{b}$-ions that are usually the most stable or the only stable isomers [4, 5]. The formation of protonated oxazolone structure for $\boldsymbol{b}$-ions is also consistent with the mechanism of peptide ion dissociations that was elucidated by detailed ab initio calculations on model diand tripeptides [6], as discussed in detail in a recent

Published online October 28, 2005

Address reprint requests to Dr. F. Tureček, Department of Chemistry, University of Washington, Bagley Hall, Box 351700, Seattle, WA 98195-1700,

USA. E-mail: turecek@chem.washington.edu authoritative review [3]. The fragmentation mechanism (Scheme 1) involves proton migration to the amide nitrogen followed by a nucleophilic attack at the amide carbonyl by the neighboring carbonyl oxygen from the $\mathrm{N}$-terminal site. This forms an intermediate with an $\mathrm{N}$-protonated oxazolone ring that can eliminate a molecule of the neutral C-terminal-truncated peptide to form the $\boldsymbol{b}$-ion [4]. Alternative structures and mechanisms for $\boldsymbol{b}$-ion formation have been proposed for peptides having polar groups in side chains of amino acid residues, His, Glu, Asn, Lys, and Arg, if these were at $\mathrm{N}$-terminal sites of the peptide bond to be cleaved [7].

Experimental support for oxazolone $\boldsymbol{b}$-ion structures was provided by CAD spectra of model systems. For example, Yalcin et al. showed that the CAD spectrum of the $\boldsymbol{b}$ ion from protonated $\mathrm{C}_{6} \mathrm{H}_{5} \mathrm{CO}-\mathrm{Gly}-\mathrm{Gly}-\mathrm{OH}$ matched that of protonated 2-phenyloxazol-5-one [4]. The reported low-energy CAD spectra showed only two fragment ions due to loss of $\mathrm{CO}$ and formation of $\mathrm{C}_{6} \mathrm{H}_{5} \mathrm{CO}^{+}$ [4]. Evidence for oxazolone-like neutral counterparts of $y$-type ions was provided by the collisional-reionization spectrum of neutral fragments eliminated from protonated $\mathrm{C}_{6} \mathrm{H}_{5} \mathrm{CO}-\mathrm{Gly}-\mathrm{Phe}-\mathrm{OH}$ that was similar to that of the neutralization-reionization mass spectrum of authentic 2-phenyloxazol-5-one cation-radical [8].

However, new questions about $\boldsymbol{b}$-ion structure have been raised recently by Haselmann and coworkers who 


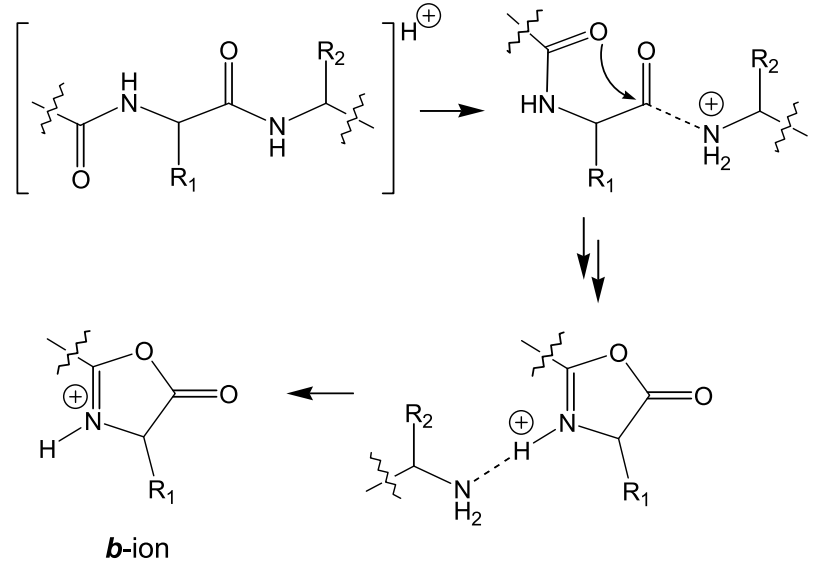

Scheme 1

observed a loss of $\mathrm{CO}$ upon electron-capture dissociation (ECD) of doubly charged $\boldsymbol{b}$ ions from several peptides. These authors hypothesized on the basis of their findings that the $\boldsymbol{b}$-ions might have open-chain acylium structures because only those could be expected to eliminate $\mathrm{CO}$ from acyl radicals produced by electron-capture neutralization [9]. In contrast, Haselmann et al. argued that elimination of $\mathrm{CO}$ from cyclic oxazolone radicals would be energetically unfavorable.

We decided to test the Haselmann hypothesis by generating authentic oxazolone radicals and study their unimolecular dissociations by neutralization-reionization mass spectrometry (NRMS) [10]. NRMS relies on the generation of gas-phase ions of well-defined structures that are separated by mass, accelerated to a high velocity (typically $100,000-200,000 \mathrm{~ms}^{-1}$ at kinetic energies in the 5-10 keV range), and discharged by a glancing collision with a gaseous neutral target [11]. For neutralization of cations, collisional electron-transfer from a thermal neutral donor, which is usually a polarizable molecule such as $\mathrm{CH}_{3} \mathrm{SSCH}_{3},\left(\mathrm{CH}_{3}\right)_{3} \mathrm{~N}$, $\mathrm{N}, \mathrm{N}$-dimethylaniline, etc., occurs on a time scale of a few femtoseconds to form the transient neutral species [12]. This ultrashort time scale for the electron-transfer guarantees that the incipient fast neutral has the structure of the ion precursor. In addition, the use of polarizable "soft" targets minimizes collisionally activated dissociation of the ions sampled for neutralization [12]. The fast neutrals are separated from the residual ions, allowed a few microseconds to dissociate, and the mixture of surviving neutral species and their dissociation products is non-selectively ionized to provide a NR mass spectrum. The latter provides a practically complete analysis of all dissociation products originating from the transient neutral intermediate [13]. In addition, ion activation in the ionizing collision can result in ion dissociations whose charged products also appear in the NR mass spectrum. Products of neutral and post-reionization ion dissociations can be distinguished by chemical or instrumental means. The former are applicable when the collision-induced and NR dis- sociations of the given ion substantially differ to be readily distinguished in the NR mass spectra. Instrumental methods for distinguishing ion and neutral dissociations rely on neutral photoexcitation [14], or variable-time measurements [15].

In our approach, simple $\boldsymbol{b}$-ions were represented by $\mathrm{N}$-protonated 2-methyl-1,3-oxazol-5-one, $3^{+}$, which we generated from 2-methyl-1,3-oxazol-one (1) and which was proved to possess a cyclic structure. Cation $3^{+}$was converted to radical 3 by collisional electron-transfer for studies of radical dissociations. To elucidate dissociation mechanisms, we used deuterium-labeled derivatives $3 \mathbf{a}^{+}$and $3 \mathbf{b}^{+}$that were converted to the corresponding radicals $\mathbf{3 a}$ and $\mathbf{3 b} \mathbf{b}$, respectively.

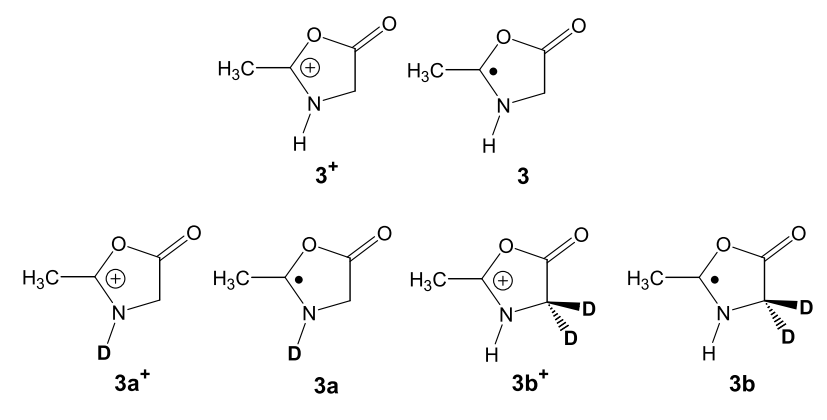

Structure 1

The experimental results were complemented by ab initio calculations at high levels of theory to provide reaction and transition-state energies for radical 3 . The transition-state energies were further used to perform Rice-Ramsperger-Kassel-Marcus (RRKM) [16] calculations of rate constants to obtain branching ratios for radical dissociations.

\section{Experimental}

\section{Materials}

Dimethyl disulfide (DMDS, 98\%), N-acetylglycine (99\%), ethyl choloroformate (97\%), $p$-toluenesulfonic acid monohydrate $(99 \%)$, and sulfuric acid- $\mathrm{d}_{2}(98 \mathrm{wt} \%$ solution in $\mathrm{D}_{2} \mathrm{O}, 99.5+$ atom $\left.\% \mathrm{D}\right)$ were purchased from Sigma-Aldrich (Milwaukee, WI). Ammonia-d $\mathrm{d}_{3}(99$ atom $\% \mathrm{D})$, glycine- $2,2-\mathrm{d}_{2}(98$ atom $\% \mathrm{D})$, methanol- $\mathrm{d}_{4}(99.8$ atom \% D), and $\mathrm{D}_{2} \mathrm{O}(99.9$ atom $\% \mathrm{D})$ were purchased from Cambridge Isotope Laboratories, Inc. (Andover, MA). Triethylamine (TEA) $(98 \%)$ was purchased from J. T. Baker, Inc. (Phillipsburg, NJ). All the compounds were used as received.

2-Methyloxazol-5-One (1). To a stirred mixture of Nacetylglycine $(5 \mathrm{~g}, 4.3 \mathrm{mmol})$ and triethylamine $(5.2 \mathrm{~g}$, $5.1 \mathrm{mmol}$ ) in $125 \mathrm{~mL}$ of dry benzene was added ethyl choloroformate $(5.1 \mathrm{~g}, 4.7 \mathrm{mmol})$ and the mixture was then stirred at room-temperature for $3 \mathrm{~h}$ [17]. The precipitated triethylamine hydrochloride was filtered off, the filtrate was evaporated, and the residue was 
purified by short-path vacuum distillation at 0.5 torr. GC mass spectrum: $m / z$ (\% relative intensity): 99 (35), 82 (6), 71 (63), 54 (13), 44 (11), 43 (100), 42 (11), 29 (92), 28 (40), 27 (45), 15 (8). ${ }^{1} \mathrm{H}-\mathrm{NMR}\left(\mathrm{CDCl}_{3}\right): 2.40\left(\mathrm{~s}, 3 \mathrm{H}, \mathrm{CH}_{3}\right)$, $4.39\left(\mathrm{~s}, 2 \mathrm{H}, \mathrm{CH}_{2}\right)$.

N-Acetylglycine Ethyl Ester (2). N-acetylglycine (5 g) and $p$-toluenesulfonic acid monohydrate $(170 \mathrm{mg})$ were dissolved in $170 \mathrm{~mL}$ of anhydrous ethanol and the solution was refluxed for $6 \mathrm{~h}$. The solution was then cooled, the solvent was evaporated in vacuo, and the residue was dissolved in $170 \mathrm{~mL}$ chloroform, and washed with $2 \times 20 \mathrm{~mL} 5 \mathrm{wt} \%$ sodium bicarbonate. The chloroform solution was dried with anhydrous sodium sulfate, filtered, the solvent was evaporated, and the product was purified by vacuum distillation. GC mass spectrum: $m / z$ (\% relative intensity): 145 (1), 100 (5), 99 (6), 73 (13), 72 (48), 43 (58), 42 (9), 30 (100), 29 (22), $28(20), 15(8)$.

$N$-Acetylglycine-2,2- $d_{2}$ (1b). Glycine-2,2- $\mathrm{d}_{2}$ (5 g) was dissolved in $34 \mathrm{~mL}$ of $2 \mathrm{M} \mathrm{NaOD}$ in $\mathrm{D}_{2} \mathrm{O}$ and acetic anhydride (13 g) was added under stirring and cooling followed by another $125 \mathrm{~mL}$ of 2M NaOD [18]. After 20 min. the mixture was acidified with $32 \mathrm{~mL}$ of $5 \mathrm{M} \mathrm{D}_{2} \mathrm{SO}_{4}$ in $\mathrm{D}_{2} \mathrm{O}$, and the aqueous layer was extracted with $6 \times$ $40 \mathrm{~mL}$ of ethyl acetate. The organic extract was dried with anhydrous $\mathrm{Na}_{2} \mathrm{SO}_{4}$, filtered, and the solvent was evaporated in vacuo to yield $2.8 \mathrm{~g}(36 \%)$ of a crystalline product.

2-methyl-1,3-oxazol-5-one-4,4- $d_{2}$ (1b). Prepared from $\mathrm{N}$-acetylglycine-2,2- $\mathrm{d}_{2}$ as described for 1. GC mass spectrum: $m / z$ (\% relative intensity): 101 (2), 100 (36), 99 (7), 83 (7), 73 (3), 72 (70), 71 (13), 55 (16), 44 (21), 43 (100), 42 (18). ${ }^{1} \mathrm{H}-\mathrm{NMR}\left(\mathrm{CDCl}_{3}\right): 2.38\left(\mathrm{~s}, 3 \mathrm{H}, \mathrm{CH}_{3}\right)$.

$N$-Acetylglycine ethyl ester-N-d (2a). Prepared by H/D transmittance exchange of the labile proton in $2(0.3 \mathrm{~g})$ by stirring in $\mathrm{CD}_{3} \mathrm{OD}(0.8 \mathrm{~mL})$ for $3 \mathrm{~h}$ and evaporating the solvent in vacuo. The crude product was used for mass spectrometric measurements without further purification. Mass spectrum: $\mathrm{m} / \mathrm{z}$ (\% relative intensity): 147 (32), 102 (14), 100 (3.5), 75 (26), 74 (76), 43 (32), 32 (100), $29(8)$.

\section{Methods}

Neutralization-reionization (NR) mass spectra were measured on a tandem quadrupole acceleration-deceleration mass spectrometer described previously [19]. Ions were generated in the gas-phase in standard electron impact (EI) or chemical ionization (CI) ion sources [12]..$^{\circ}$ The $^{\circ}$ source $^{\circ}$ conditions $^{\circ}$ were $^{\circ}$ as $^{\circ}$ follows: ${ }^{\circ}$ emission current, $500 \mu \mathrm{A}$ for EI and $1 \mathrm{~mA}$ for CI. The electron energy was tuned for the best signal but typically was $70 \mathrm{eV}$ for EI and $100 \mathrm{eV}$ for CI. The source temperature was $200-220^{\circ} \mathrm{C}$. Liquid samples were degassed by several freeze-pump-thaw cycles and introduced into the ion source from a glass liquid probe at room- temperature. Due to its high volatility, the triethylamine probe was kept at $0^{\circ} \mathrm{C}$ throughout each experimental period to keep the pressure stable. $\mathrm{NH}_{3}$ and $\mathrm{ND}_{3}$ were used as CI reagent gases at pressures 8.0-9.0 $\times 10^{-5}$ torr as read on an ionization gauge located at the diffusion pump intake. The ions were extracted from the source, transmitted through a radio-frequency-only quadrupole filter, accelerated to $7250 \mathrm{eV}$ and focused on a collision cell floated at $-7170 \mathrm{~V}$, where dimethyldisulfide vapor was admitted at pressures such as to achieve $70 \%$ ion beam transmission. According to Poisson statistics, out of the $30 \%$ ions that underwent collisions $83 \%$ collided only once. Residual ions and neutrals were allowed to drift to a four-segment conduit maintained at $+250 \mathrm{~V}$ that reflected the ions while allowing the neutrals to pass through. The neutral drift time was 5.1 $\mu$ s for species of $100 \mathrm{Da}$ mass. The neutrals were non-selectively reionized by collisions with oxygen at pressures allowing $70 \%$ beam transmittance. The ions formed then were decelerated to $75-80 \mathrm{eV}$, energy filtered, and analyzed by a quadrupole mass filter that was operated at unit mass resolution.

The quadrupole analyzer and the deceleration voltage were scanned in link to allow transmission of ions of mass $m_{\mathrm{f}}$ that have kinetic energies $\left(e V_{\mathrm{f}}\right)$ according to eq 1 , where $m_{\mathrm{p}}$ is the precursor ion mass and $V_{\mathrm{p}}$ is the acceleration $^{\circ}$ potential $^{\circ}[19]$.

$$
V_{f}=V_{p} \frac{m_{f}}{m_{p}}
$$

In case that there are precursor ions at adjacent masses $\left(m_{\mathrm{p} 1}\right.$ and $\left.m_{\mathrm{p} 2}\right)$ forming a common fragment $m_{\mathrm{f}}$, the latter is transmitted through the energy filter lens if the difference in the product ion kinetic energies $(\Delta \mathrm{eV})$ is comparable to or smaller than the filter energy bandpass width $\Delta T_{\text {pass }} \approx$ $40^{\circ} \mathrm{eV}^{\circ}\left(\mathrm{eq}^{\circ} 2\right)^{\circ}[19]^{\circ}{ }^{\circ}$ For $^{\circ}$ example, $^{\circ}$ product $^{\circ}$ ions $^{\circ}$ at $^{\circ} \mathrm{m} / z 57$ produced from 7-keV precursor ions of $m / z 100$ and 101 will have $(\Delta e V)=40 \mathrm{eV}$ and thus be transmitted and appear in the NR mass spectrum at $m / z 57$.

$$
\Delta(e V)=e V_{p} m_{f}\left|\frac{1}{m_{p 1}}-\frac{1}{m_{p 2}}\right| \leq \Delta T_{\text {pass }}
$$

The instrument was tuned daily to match the reference NR mass spectrum of $\mathrm{CS}_{2}$. Typically, 50 repetitive scans were accumulated per spectrum at a 1 mass unit/s scan rate, corresponding to 200 data points per peak.

${ }^{1} \mathrm{H}-\mathrm{NMR}$ spectra were measured on an Bruker Avance 300 spectrometer at $300.13 \mathrm{MHz}$ in $\mathrm{CDCl}_{3}$ at $25^{\circ} \mathrm{C}$. Gaschromatography mass spectrometry was performed on an HP 5971A instrument equipped with a silicone elastomer DB5 GC capillary column. Electron impact and chemical ionization mass spectra were measured on a JEOL HX-110 double focusing instrument equipped with $\mathrm{EI}$ and $\mathrm{CI}$ ion sources. Samples were introduced from a direct probe at $50{ }^{\circ} \mathrm{C}$. Triethylamine was introduced from a gas reservoir. Collisionally activated dissociation (CAD) spectra were 
measured on the JEOL HX-110 instrument by scanning the electrostatic $(\mathrm{E})$ and magnet $(\mathrm{B})$ analyzers while maintaining a constant $\mathrm{B} / \mathrm{E}$ ratio (B/E linked scan). Air as the collision gas was admitted to the first field-free region at pressures to achieve 50 and $70 \%$ beam transmittance at 10 $\mathrm{keV}$. Typically 20-30 scans were collected and averaged. The low $\Delta T_{\text {pass }}$ of the electrostatic analyzer $(<2 \mathrm{eV})$ and high ion kinetic energy secured that precursor ions at adjacent masses were completely separated throughout the entire mass range of $m / z 10-103$.

\section{Calculations}

Standard ab initio and density functional theory calculations were performed using the Gaussian 03 suite of programs ${ }^{\circ}[20] .{ }^{\circ}$ Geometries $^{\circ}$ were $^{\circ}$ optimized $^{\circ}$ with $^{\circ}$ Becke's hybrid ${ }^{\circ}$ functional ${ }^{\circ}(\mathrm{B} \mathrm{LYP})^{\circ}[21]^{\circ}$ using $^{\circ}$ the ${ }^{\circ} 6-31^{\circ}++{ }^{\circ} \mathrm{G}(\mathrm{d}, \mathrm{p})$ basis set. The Supplementary Material section containing tables of optimized geometries (cartesian coordinate formate, standard orientation) can be accessed in the electronic version of this article. The same level of theory was used for frequency analysis to characterize local energy minima (all real frequencies) and transition states as first-order saddle points (one imaginary frequency). Improved energies were obtained by single-point calculations ${ }^{\circ}$ using $^{\circ} \mathrm{B} \mathrm{LY}^{\circ} \mathrm{P}^{\circ}$ and ${ }^{\circ}$ Møller-Plesset ${ }^{\circ}$ theory ${ }^{\circ}[22]^{\circ}$ truncated at second-order (MP2, frozen core) and the larger triple- $\zeta$ split valence $6-311++\mathrm{G}(3 \mathrm{df}, 2 \mathrm{p})$ basis set furnished with multiple shells of polarization functions at $C$, $\mathrm{N}, \mathrm{O}$, and $\mathrm{H}$, one shell of diffuse $\mathrm{s}$ and $\mathrm{p}$ functions at $\mathrm{C}, \mathrm{N}$, and $\mathrm{O}$, and one shell of diffuse $\mathrm{s}$ functions at $\mathrm{H}$. Spin unrestricted calculations (UB3LYP and UMP2) were performed for open-shell systems. Spin contamination was negligible in UB3LYP computations, as evidenced by the expectation values of the spin operator that were all $\left\langle S^{2}\right\rangle \leq$

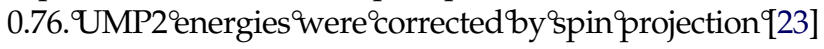
(PMP2) that lowered $\langle S\rangle$ to $\leq 0.76$ and resulted in 6.7 millihartree energy corrections (root mean square deviation). The B3LYP and MP2 or PMP2 single point energies were averaged according to the previously reported B3$\mathrm{MP}^{\circ}$ scheme $^{\circ}[24]^{\circ}$ that $^{\circ}$ has $^{\circ}$ been $^{\circ}$ shown $^{\circ}$ to ${ }^{\circ}$ achieve $^{\circ}$ improved accuracy at the level of highly correlated composite $\mathrm{ab}$ initio methods by canceling small errors inherent to the ${ }^{\circ} \mathrm{B} 3 \mathrm{LYP}^{\circ}$ and ${ }^{\circ} \mathrm{MP} 2^{\circ}$ approximations ${ }^{\circ}[25]^{\circ} .^{\circ}$ Another ${ }^{\circ}$ set $^{\circ}$ of energies was obtained for selected species from single point $^{\circ}$ calculations $^{\circ}$ with $^{\circ}$ coupled $^{\circ}$ cluster $^{\circ}$ theory ${ }^{\circ}[26]^{\circ} \mathrm{em}^{-}$ ploying single, double and disconnected triple excitations of $^{\circ}$ valence $^{\circ}$ electrons ${ }^{\circ}[27],{ }^{\circ} \operatorname{CCSD}(\mathrm{T}),{ }^{\circ}$ and $^{\circ}$ the $^{\circ} 6-311 G(\mathrm{~d}, \mathrm{p})$ basis set. The energies were extrapolated to $\operatorname{CCSD}(\mathrm{T}) /$ $6-311+\mathrm{G}(2 \mathrm{~d}, \mathrm{p})$ and $\operatorname{CCSD}(\mathrm{T}) / 6-311++\mathrm{G}(3 \mathrm{df}, 2 \mathrm{p})$ using standard ${ }^{\circ}$ linear ${ }^{\circ}$ formulas, ${ }^{\circ} \mathrm{eq}^{\circ} 3^{\circ}$ and $^{\circ} 4^{\circ}[28]$.

$$
\begin{aligned}
& E[\operatorname{CCSD}(\mathrm{T}) / 6-311+\mathrm{G}(2 \mathrm{~d}, \mathrm{p})] \approx E[\operatorname{CCSD}(\mathrm{T}) / \\
& 6-311 \mathrm{G}(\mathrm{d}, \mathrm{p})]+E[\mathrm{MP} 2 / 6-311+\mathrm{G}(2 \mathrm{~d}, \mathrm{p})] \\
& -E[\mathrm{MP} 2 / 6-311 \mathrm{G}(\mathrm{d}, \mathrm{p})]
\end{aligned}
$$

$$
\begin{aligned}
& E[\operatorname{CCSD}(\mathrm{T}) / 6-311++\mathrm{G}(3 \mathrm{df}, 2 \mathrm{p})] \\
& \quad \approx E[\operatorname{CCSD}(\mathrm{T}) / 6-311 \mathrm{G}(\mathrm{d}, \mathrm{p})]+E[\mathrm{MP} 2 / 6-311 \\
& \quad++\mathrm{G}(3 \mathrm{df}, 2 \mathrm{p})]-E[\mathrm{MP} 2 / 6-311 \mathrm{G}(\mathrm{d}, \mathrm{p})]
\end{aligned}
$$

These effective $\operatorname{CCSD}(\mathrm{T})$ calculations gave similar relative energies for the species under study, and so only results from the larger basis set expansion (eq 4) are reported here. The B3-MP2 and $\operatorname{CCSD}(\mathrm{T})$ energies were used to calculate relative energies that were corrected for zero-point vibrational contributions. The reported relative energies thus correspond to $0 \mathrm{~K}$ unless stated otherwise. Enthalpy corrections and entropies were calculated from B3LYP/6-31 + + G(d,p) harmonic frequencies and moments of inertia within the rigid rotor-harmonic oscillator approximation. Complete active $^{\circ}$ space $^{\circ}(\mathrm{CASSCF})^{\circ}[29]^{\circ} \mathrm{Calculations}^{\circ}$ were $^{\circ}$ carried $^{\circ}$ out to investigate selected dissociation pathways and used the $6-31++G(d, p)$ basis set.

RRKM calculations were performed using Hase's program $[30]^{\circ}$ that $^{\circ}$ was $^{\circ}$ recompiled $^{\circ}$ and ${ }^{\circ}$ run $^{\circ}$ under ${ }^{\circ} W$ in-

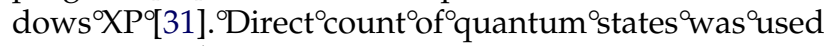
in $2 \mathrm{~kJ} \mathrm{~mol}^{-1}$ steps from the transition-state energy up to $300 \mathrm{~kJ} \mathrm{~mol}^{-1}$ above it. Rotational states were treated adiabatically. The calculated microscopic rate constants, $k(E, J, K)$, were Boltzmann averaged over the rotational states at $473 \mathrm{~K}$, corresponding to the ion source temperature that defines the precursor ion rotational temperature, to give microcanonical rate constants $k(E)$.

\section{Results and Discussion}

\section{Ion Formation and Dissociations}

A logical pathway to generate ion $3^{+}$is by selective protonation of a cyclic neutral precursor, 2-methyl-1,3oxazol-5-one (1). Combined MP2 and B3LYP/6-311 ++ $\mathrm{G}(3 \mathrm{df}, 2 \mathrm{p})$ and $\operatorname{CCSD}(\mathrm{T})$ calculations of the topical proton affinities (PA) in $\mathbf{1}$ point to $\mathrm{N}-3$ as the most basic site of PA $=877 \mathrm{~kJ} \mathrm{~mol}^{-1}$. The $\mathrm{O}-1\left(\mathrm{PA}=791 \mathrm{~kJ} \mathrm{~mol}^{-1}\right)$ and O-6 $\left(\mathrm{PA}=736 \mathrm{~kJ} \mathrm{~mol}^{-1}\right)$ positions are substantially less basic. These features allowed us to use $\mathrm{NH}_{4}{ }^{+}$as a gas-phase acid $\left(\mathrm{PA}\left(\mathrm{NH}_{3}\right)^{\circ}={ }^{\circ} 854^{\circ} \mathrm{kJ}^{\circ} \mathrm{mol}^{-1}\right)^{\circ}[32]^{\circ}$ for mildly exothermic and selective protonation of $\mathbf{1}$ at $\mathrm{N}-3$ to form the desired ion $3^{+}$. Protonations with $\mathrm{NH}_{4}{ }^{+}$at positions O-1 and O-6 in $\mathbf{1}$ are endothermic and therefore ${ }^{\text {both }}$ kinetically $^{\circ}[33]^{\circ}$ and ${ }^{\circ}$ thermodynamically ${ }^{\circ}$ disfavored under chemical ionization conditions in the gasphase [34]. ${ }^{\circ} \mathrm{CI}-\mathrm{NH}_{3}$ of $\mathbf{1}$ formed the desired ion $\mathbf{3}^{+}$at $\mathrm{m} / \mathrm{z}$ 100 that was characterized by accurate mass measurements (measured 100.0393, $\mathrm{C}_{4} \mathrm{H}_{6} \mathrm{NO}_{2}$ requires 100.0398) and CAD mass spectra, as described below.

Another route to ion $3^{+}$or its isomers is by dissociative ionization with $70-\mathrm{eV}$ electrons of an acyclic precursor, $\mathrm{N}$-acetylglycine ethyl ester, that eliminates $\mathrm{OC}_{2} \mathrm{H}_{5}$ to produce a $\mathrm{C}_{4} \mathrm{H}_{6} \mathrm{NO}_{2}{ }^{+}$ion at $\mathrm{m} / \mathrm{z} 100$ that was also characterized by accurate mass measurements and CAD mass spectra. This ion is denoted as $3^{\prime+}$. The loss of $\mathrm{OC}_{2} \mathrm{H}_{5}$ is accompanied by an elimination of $\mathrm{C}_{2} \mathrm{H}_{5} \mathrm{OH}$ that produces a $\mathrm{C}_{4} \mathrm{H}_{5} \mathrm{NO}_{2}{ }^{+\cdot}$ ion at the adjacent $m / z 99$. 


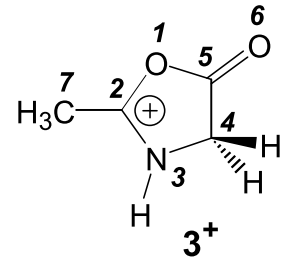

Structure 2

We also prepared deuterium-labeled derivatives of $3^{+}$and characterized them by accurate mass measurements and CAD spectra. The N-D labeled ion $3 \mathbf{a}^{+}(\mathrm{m} / \mathrm{z}$ 101) was prepared by $\mathrm{ND}_{3} / \mathrm{CI}$ of $\mathbf{1}$. The $4,4-\mathrm{D}_{2}$ labeled ion $3 \mathbf{b}^{+}$was prepared by $\mathrm{NH}_{3} / \mathrm{CI}$ of $\mathbf{1 b}$. N-D and $4,4-\mathrm{D}_{2}$ analogs $3 \mathbf{a}^{\prime+}$ and $3 \mathbf{b}^{\prime+}$ were also prepared by $70-\mathrm{eV}$ dissociative ionization of N-D-acetylglycine ethylester and $\mathrm{N}$-acetyl-2,2- $\mathrm{D}_{2}$-glycine ethyl ester, respectively.

The ${ }^{\circ} \mathrm{CAD}{ }^{\circ}$ spectra ${ }^{\circ}$ of $^{\circ} 3^{+{ }^{\circ}}$ and $^{\circ} 3^{\prime+}{ }^{\circ}$ show ${ }^{\circ}$ similar ${ }^{\circ}$ dissociations $^{\circ}$ (Figure $\left.{ }^{\circ} 1\right){ }^{\circ}$ Unimolecular ${ }^{\circ}$ dissociations ${ }^{\circ}$ of ${ }^{\circ}$ metastable $3^{+}$and $3^{\prime+}$ proceed by elimination of $\mathrm{CO}$ to give the $m / z 72$ fragment ions that are also abundant in the CAD spectra. The other collision-induced dissociations of $\mathbf{3}^{+}$and $\mathbf{3}^{\prime+}$ are loss of $\mathrm{H}\left(\mathrm{m} / z\right.$ 99), loss of $\mathrm{CO}+\mathrm{CH}_{3}$ $(\mathrm{m} / \mathrm{z} 57)$, and the formation of $\mathrm{CH}_{3} \mathrm{CO}^{+}(\mathrm{m} / \mathrm{z} 43)$ and $\mathrm{CH}_{2}=\mathrm{NH}_{2}{ }^{+}(m / z 30)$. The substantially greater relative abundance of the $(\mathrm{M}-\mathrm{CO})^{+}$ion from $3^{\prime+}$ can be accounted for by a higher fraction of metastable ions produced by electron impact-induced dissociation of the $\mathrm{N}$-acetylglycine ester precursor, compared to the metastable fraction of $\mathbf{3}^{+}$generated under CI conditions by mildly exothermic proton transfer. Other than the

(a)

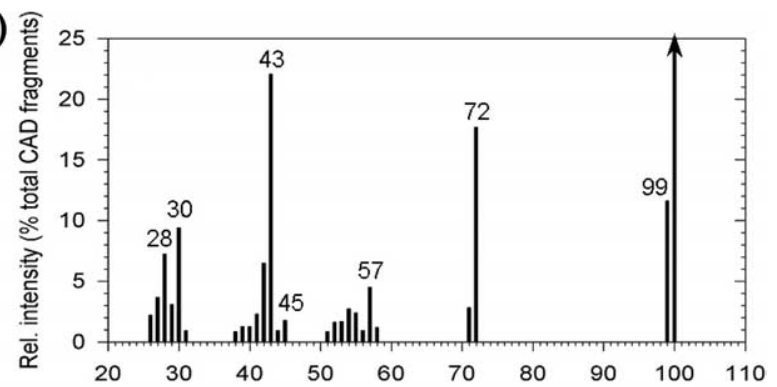

(b)

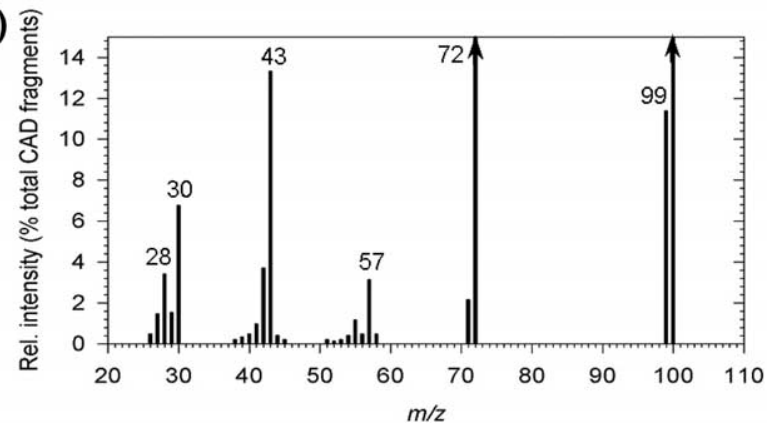

Figure 1. 10-keV CAD mass spectra of (a) ion $3^{+}$from $\mathrm{CI}-\mathrm{NH}_{3}$ protonation of 2-methyloxazol-5-one, and (b) ion $3^{\prime+}$ from dissociative ionization of N-acetylglycine ethyl ester. The peaks denoted by arrows are truncated on the relative intensity scale.

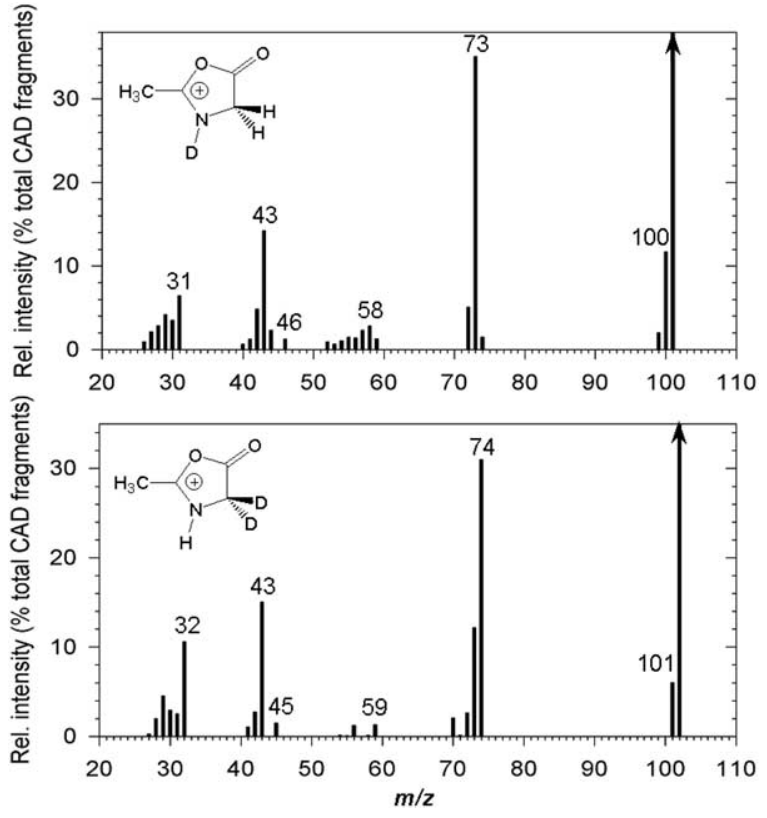

Figure 2. 10-keV CAD mass spectra of (top) ion $3 \mathbf{a}^{+}$and (bottom) ion $3 \mathbf{b}^{+}$. The peaks of precursor ions denoted by arrows are truncated on the relative intensity scale.

$\mathrm{m} / \mathrm{z} 72$ ion relative intensity, the CAD spectra of $3^{+}$and $3^{\prime+}$ are practically identical.

Deuterium labeling in $3 \mathbf{a}^{+}$and $3 \mathbf{b}^{+}$manifests itself by mass shifts in the pertinent CAD mass spectra (Figure 2). ${ }^{\text {Both }} 3 \mathbf{a}^{+}{ }^{\circ}$ and $3 \mathbf{b}^{+}{ }^{\circ}$ show ${ }^{\circ}$ mainly 9 oss ${ }^{\circ}$ of ${ }^{\circ}$ qight hydrogen atom, indicating that the latter originates from the exocyclic methyl group to form a 2-methylene1,3-oxazolin-5-one cation-radical $\left(\mathbf{7}^{+}\right)$(Scheme 2$)$. Eliminations of $\mathrm{CO}$ and $\mathrm{CO}+\mathrm{CH}_{3}$ show retention of the deuterium label in the fragment ions, as corroborated by the relevant mass shifts in the CAD spectra $(\mathrm{m} / z 73$ and 58 from $3 \mathbf{a}^{+}$and $m / z 74$ and 59 from $3 \mathbf{b}^{+}$). The acetyl ion at $m / z 43$ does not contain deuterium when formed from $3 \mathbf{a}^{+}$and $3 \mathbf{b}^{+}$. The mass shifts $m / z 30 \rightarrow \mathrm{m} / z$ 31 and $m / z 30 \rightarrow m / z 32$ for $3 \mathbf{a}^{+}$and $3 \mathbf{b}^{+}$, respectively, indicate that the $\mathrm{CH}_{2}=\mathrm{NH}_{2}{ }^{+}$cations incorporate the $\mathrm{N}-3-\mathrm{C}-4$ moiety that receives a hydrogen atom from the methyl group in the course of dissociation.

The facile elimination of $\mathrm{CO}$ from $3^{+}$is consistent with the energetics of this dissociation that has been

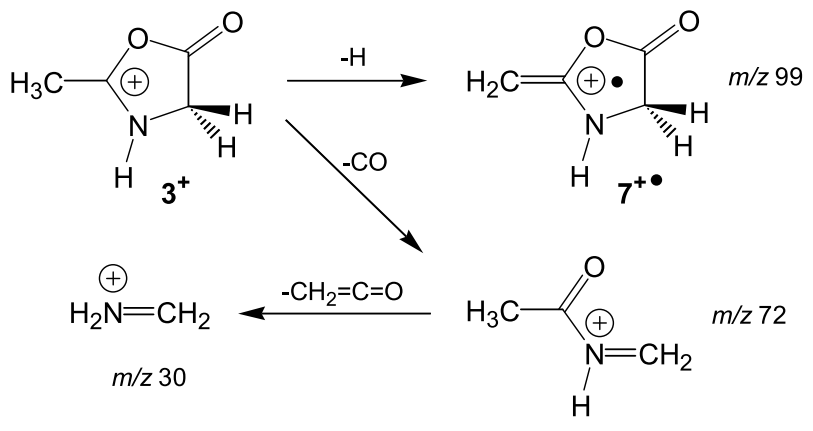

Scheme 2 


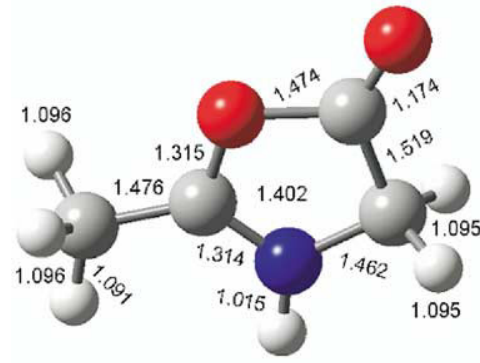

$3^{+}$

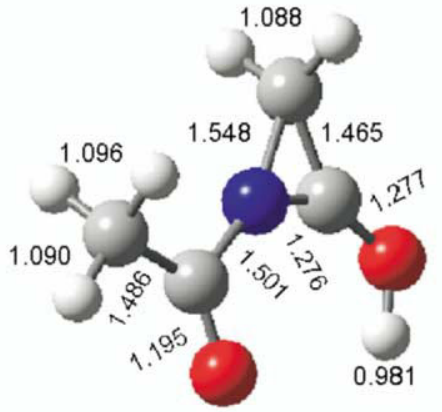

$6 a^{+}$

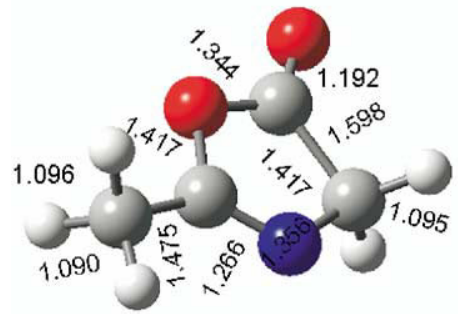

$1^{+*}$

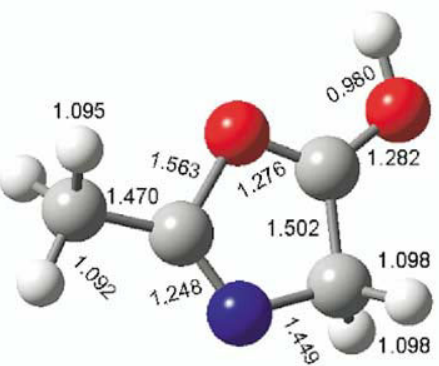

$4^{+}$

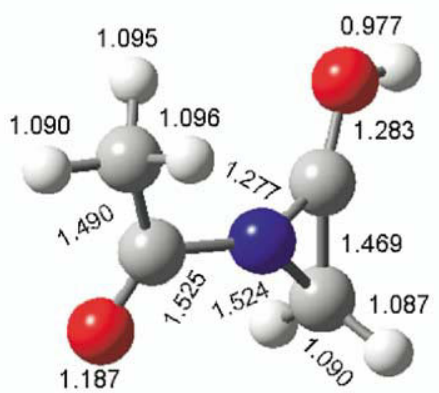

$6 b^{+}$

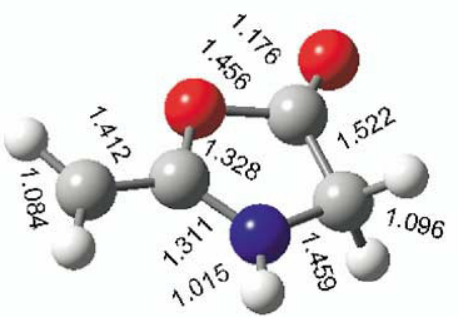

$7^{+\infty}$

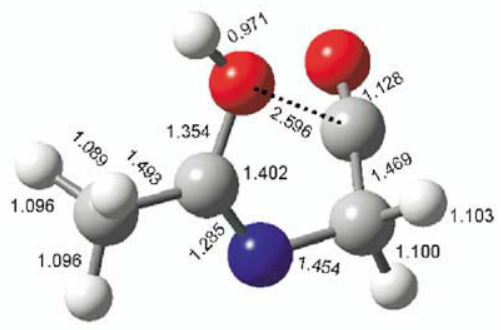

$5^{+}$

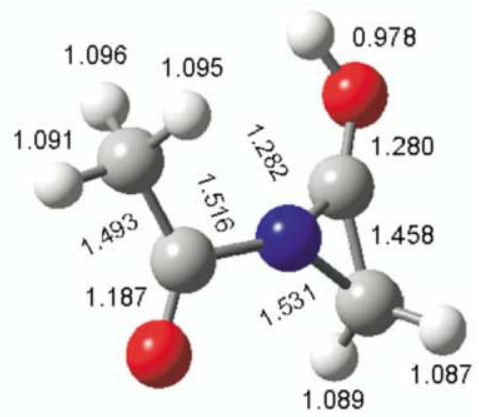

$6 c^{+}$

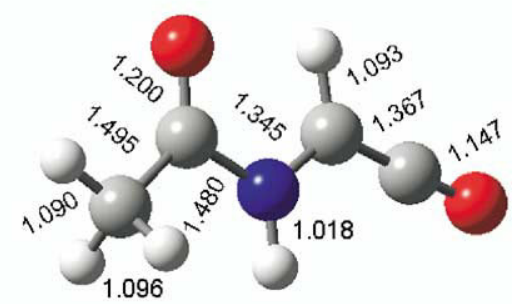

$8^{+\cdot}$

Figure 3. B3LYP/6-31 ++ G(d,p) optimized structures of ions $3^{+}, 4^{+}, 5^{+}, \mathbf{6 a} \mathbf{a}^{+}-6 \mathrm{c}^{+}, \mathbf{1}^{+}, \mathbf{7}^{+*}$, and $\mathbf{8}^{+ \text {. }}$. Bond lengths in angstroms.

shown to occur in a variety of peptide $\boldsymbol{b}$ ions and was calculated to require low activation energies (113-119 kJ $\left.\mathrm{mol}^{-1}\right)^{\circ}$ in $^{\circ}$ related $^{\circ}$ oxazolone ${ }^{\circ}$ cations $^{\circ}[6]$.

\section{Ion Structures and Dissociation Energetics}

The ion dissociations observed upon CAD can be related to the ion relative stabilities and dissociation energies. We obtained by DFT calculations several ion structures that were local energy minima, as shown in Figure ${ }^{\circ} .^{\circ} \mathrm{N}$-protonated ${ }^{\circ}$ oxazolone ${ }^{\circ} 3^{+}{ }^{\circ}$ is ${ }^{\circ}$ the $e^{\circ}$ most ${ }^{\circ}$ stable ion $^{\circ}$ isomer $^{\circ}$ of $^{\circ}$ those $^{\circ}$ we $^{\circ}$ investigated $^{\circ}\left(\right.$ Table $\left.^{\circ} 1\right) .^{\circ}$ The optimized structure shows a planar ring and rather conventional lengths of the $\mathrm{C}-\mathrm{C}, \mathrm{C}-\mathrm{O}$, and $\mathrm{C}-\mathrm{N}$ bonds $^{\circ}\left(\text { Figure }^{\circ} 3\right)^{\circ}[5]{ }^{\circ}{ }^{\circ}$ The ${ }^{\circ}$ carbonyl-protonated ${ }^{\circ}$ ion $^{\circ}\left(4^{+}\right)$ shows a conspicuously elongated $\mathrm{O}-1-\mathrm{C}-2$ bond $(1.563$ $\AA$, ${ }^{\circ}$ Figure $\left.^{\circ} 3\right)^{\circ}$ that $^{\circ}$ indicates ${ }^{\circ}$ destabilization ${ }^{\circ}$ of ${ }^{\circ}$ the ${ }^{\circ}$ oxazolone ring. The $\mathrm{O}-1-\mathrm{C}-5$ ring bond is completely broken $(2.596 \AA)$ in the O-1-protonated isomer $5^{+}$which shows a gauche geometry that can be described as an acylium cation that is weakly internally solvated with the ${ }^{\circ}$ oxygen ${ }^{\circ}$ atom $^{\circ}$ of $^{\circ}$ the ${ }^{\circ}$ acetenolimine ${ }^{\circ}$ group $^{\circ}$ (Figure ${ }^{\circ}$ ). Ions $4^{+}$and $5^{+}$are substantially destabilized against $3^{+}$ at all levels of theory, e.g., by 83 and $140 \mathrm{~kJ} \mathrm{~mol}^{-1}$, respectively, according to $\operatorname{CCSD}(T) / 6-311++G(3 d f, 2 p)$ calculations $^{\circ}\left(\right.$ Table $\left.^{\circ} 1\right){ }^{\circ}$ Attempts $^{\circ}$ were $^{\circ}$ also $^{\circ}$ made $^{\circ}$ to obtain local energy minima for open-chain isomers of $3^{+}$. However, regardless of the starting geometry, gradient optimizations including complete force constant analysis resulted in ring closure yielding $3^{+}$. Hence we conclude that open-chain isomers of $3^{+}$are either inherently unstable or represent extremely shallow minima on the potential energy surface. Interestingly, Paizs et al. reported a high-energy, open-chain, gauche isomer for protonated 1,3-oxazol-5-one, but not for 2,3-dimethyl- ${ }^{\circ}$ and $^{\circ} 2$-isobutyloxazolones ${ }^{\circ}$ [6]. ${ }^{\circ}$ Several conformers of another cyclic ion isomer, carbonylprotonated $\mathrm{N}$-acetylaziridinone $\left(6 \mathrm{a}^{+}-6 \mathrm{c}^{+}\right)$, have been 
Table 1. Ion relative and dissociation energies

\begin{tabular}{|c|c|c|c|c|c|}
\hline \multirow[b]{3}{*}{ Species/reaction } & \multicolumn{5}{|c|}{ Energy $^{a b}$} \\
\hline & \multirow[b]{2}{*}{$\begin{array}{c}6-31++G(d, p) \\
\text { B3LYP }\end{array}$} & \multicolumn{4}{|c|}{$6-311++G(3 d f, 2 p)$} \\
\hline & & B3LYP & MP2 & B3-MP2 & $\operatorname{ccsD}(T)$ \\
\hline $3^{+}$ & 0 & 0 & 0 & 0 & 0 \\
\hline $4^{+}$ & 84 & 83 & 87 & 85 & 83 \\
\hline $5^{+}$ & 152 & 143 & 135 & 139 & 140 \\
\hline $6 \mathbf{a}^{+}$ & 222 & 221 & 226 & 223 & 229 \\
\hline $6 b^{+}$ & 227 & 225 & 228 & 226 & 232 \\
\hline $6 c^{+}$ & 239 & 236 & 238 & 237 & 242 \\
\hline $\mathbf{3}^{+} \rightarrow \mathrm{CH}_{3} \mathrm{CONH}=\mathrm{CH}_{2}^{+}+\mathrm{CO}$ & 113 & 108 & 114 & 111 & 97 \\
\hline $3^{+} \rightarrow \mathrm{CH}_{3} \mathrm{CO}^{+}+\mathrm{NH}=\mathrm{CH}_{2}+\mathrm{CO}$ & 278 & 260 & 265 & 262 & 254 \\
\hline $3^{+} \rightarrow 7^{+\bullet}+\mathrm{H}^{\bullet}$ & 396 & 391 & 391 & 391 & 401 \\
\hline $\mathbf{3}^{+} \rightarrow 1^{+\bullet}+\mathrm{H}^{\bullet}$ & 507 & 502 & 498 & 500 & 523 \\
\hline $\mathbf{3}^{+} \rightarrow \mathbf{8}^{+\bullet}+\mathrm{H}^{\bullet}$ & 423 & 409 & 413 & 411 & 434 \\
\hline
\end{tabular}

an units of $\mathrm{kJ} \mathrm{mol}^{-1}$.

blncluding B3LYP/6-31++G(d,p) zero-point vibrational corrections and referring to $0 \mathrm{~K}$.

cFrom basis set expansion according to eq 4 .

found to be local energy minima. However, all these ion isomers are substantially less stable than $3^{+}$ (Table $\left.{ }^{\circ} 1\right)$.

We also ${ }^{\circ}$ report ${ }^{\circ}$ the ${ }^{\circ}$ dissociation $^{\circ}$ energies ${ }^{\circ}$ of $3^{+}{ }^{\circ}$ (Table $1)^{\circ}$ to $^{\circ}$ assess $^{\circ}$ the $e^{\circ}$ energetics ${ }^{\circ}$ of $^{\circ}$ the $e^{\circ}$ ion $^{\circ}$ dissociations. Elimination of $\mathrm{CO}$ forming the $\mathrm{m} / \mathrm{z} 72$ ion is found to have the lowest thermochemical threshold at $97 \mathrm{~kJ}$ $\mathrm{mol}^{-1}$ relative to $3^{+}$. This result is consistent with the dominant metastable-ion dissociation of $3^{+}$. We note that Paizs et al. reported somewhat lower dissociation energies for loss of $\mathrm{CO}$ from protonated 1,3-oxazol-5one and 2,3-dimethyl-1,3-oxazol-5-one at comparable levels ${ }^{\circ}$ of ${ }^{\circ}$ theory ${ }^{\circ}[6]{ }^{\circ}{ }^{\circ}$ Consecutive ${ }^{\circ}$ dissociation ${ }^{\circ}$ by $^{\circ}$ elimination of $\mathrm{CO}$ and $\mathrm{CH}_{2}=\mathrm{NH}$ to form $\mathrm{CH}_{3} \mathrm{CO}^{+}$requires an ${ }^{\circ}$ additional ${ }^{\circ} 157^{\circ} \mathrm{kJ}^{\circ} \mathrm{mol}^{-1^{\circ}}$ (Table 1 1). ${ }^{\circ}{ }^{\circ}{ }^{\circ}{ }^{\circ}$ Contrast, ${ }^{\circ}$ loss ${ }^{\circ}$ of the methyl $\mathrm{H}$-atom is a high-energy dissociation that requires $391 \mathrm{~kJ} \mathrm{~mol}^{-1}$ at the thermochemical threshold when forming the most stable 2-methylenoxazolin-5one cation-radical $7^{+\cdot}$. Losses of other hydrogen atoms from $3^{+}$, e.g., from N-3 to form [2-methyl-1,3-oxazol-5one $]^{+\cdot}\left(\mathbf{1}^{+\cdot}\right)$ or from C-4 to form [N-acetylaminoketene $]^{+\cdot}\left(8^{+\cdot}\right)$, require even higher threshold energies (Table ${ }^{\circ} 1$ ). ${ }^{\circ}$ The $^{\circ}$ fact ${ }^{\circ}$ that $^{\circ}{ }^{\circ}$ oss $^{\circ}$ of $^{\circ} \mathrm{H}^{\circ}$ occurs $^{\circ}$ competitively with the other low-energy dissociations indicates involvement of electronically excited states of $3^{+}$upon collisional ${ }^{\circ}$ activation ${ }^{\circ} \mathrm{at}^{\circ} 10^{\circ} \mathrm{keV}^{\circ}[35] .{ }^{\circ} \mathrm{In}^{\circ}$ summary, ${ }^{\circ}$ the major ion dissociations upon CAD of $3^{+}$, as identified by isotope labeling, can be correlated with the relative energies of the products.

\section{Neutralization-Reionization and Radical Dissociations}

Collisional neutralization of $3^{+}$produces radical 3 whose ${ }^{\circ} \mathrm{NR}^{\circ}$ mass $^{\circ}$ spectrum ${ }^{\circ}{ }^{\circ}{ }^{\circ}$ isplayed ${ }^{\circ}{ }^{\circ}{ }^{\circ}$ Figure ${ }^{\circ} 4$. The spectrum shows extensive dissociations so that only a small fraction of surviving 3 is reionized and appears as survivor ${ }^{\circ}$ ions $^{\circ}$ at ${ }^{\circ} \mathrm{m} / \mathrm{z} 100^{\circ}$ (Figure $\left.{ }^{\circ} 4 \mathrm{a}\right) .{ }^{\circ}$ Out $^{\circ}$ of $^{\circ}$ the ${ }^{\circ}$ several dissociation pathways observed, the most significant ones give rise to the products at $m / z 99,71,57,43,42,29$, and 28. The products were identified with the help of deuterium labeling as illustrated by the NR mass spectra ${ }^{\circ}$ of $^{\circ} 3 \mathbf{a}$ and ${ }^{\circ} \mathbf{3 b}$ (Figure ${ }^{\circ} 4 \mathrm{~b},{ }^{\circ} \mathrm{C}$ ). ${ }^{\circ} \mathrm{The}^{\circ} \mathrm{loss}^{\circ} \mathrm{of}^{\circ} \mathrm{H}^{\circ}$ from ${ }^{\circ} \mathbf{3 a}$ involves both light hydrogen and deuterium, as evidenced by the peaks at $m / z 100$ and 99 . The loss of $\mathrm{H}$ or $\mathrm{D}$ from $\mathbf{3} \mathbf{b}$ is difficult to distinguish because of a poorer signal to noise ratio in the spectrum. Nevertheless, it appears $^{\circ}$ from $^{\circ}$ the ${ }^{\circ}$ comparison $^{\circ}$ of ${ }^{\circ}$ the $^{\circ}$ Figure $^{\circ} 3 a^{\circ}$ and Figure $3 b, c^{\circ}$ spectra ${ }^{9}$ that ${ }^{\circ}$ oss $^{\circ}$ of ${ }^{\circ}$ is hampered by kinetic isotope effects. The loss of $29 \mathrm{Da}(\mathrm{m} / \mathrm{z} 71)$ shows a partial mass shift to $\mathrm{m} / \mathrm{z} 72^{\circ}$ (Figure $4 \mathrm{~b}$ ) ${ }^{\circ}$ and ${ }^{\circ} \mathrm{o} m / z 3^{\circ}$ (Figure $4 \mathrm{c}$ ). An $m / z 71$ fragment is also present in the NR mass spectrum of $\mathbf{1}^{+\cdot}$ at $[\mathrm{m} / \mathrm{z} 71] /[\mathrm{m} / \mathrm{z} 99]=1.2$. This indicates that the formation of the $\mathrm{m} / \mathrm{z} 71$ fragment from 3 involves consecutive dissociations by loss $\mathrm{H}$ and $\mathrm{CO}$. The $\mathrm{m} / \mathrm{z} 42$ and 43 fragments show no retention of deuterium when formed from $\mathbf{3} \mathbf{a}$ and $\mathbf{3 b}$, and hence must originate from the $\mathrm{CH}_{3} \mathrm{C}-\mathrm{O}$ moiety in 3 . The $\mathrm{m} / \mathrm{z}$ 29 fragment shows only a partial $1 \mathrm{u}$ shift to $\mathrm{m} / \mathrm{z} 30$ in the spectra of $\mathbf{3 a}$ and $\mathbf{3} \mathbf{b}$, but no dominant shift to $\mathrm{m} / \mathrm{z} 31$ in the spectrum of the later radical. This indicates that the formation of the $\mathrm{m} / \mathrm{z} 29$ species $\left(\mathrm{HCO}, \mathrm{COH}\right.$, or $\mathrm{CH}_{2}$ $=\mathrm{NH})$ is accompanied by $\mathrm{H} / \mathrm{D}$ migrations. The NR mass spectra of $\mathbf{3}, \mathbf{3} \mathbf{a}$ and $\mathbf{3} \mathbf{b}$ are dominated by the $\mathrm{m} / \mathrm{z}$ 28 fragment. Deuterium labeling in $\mathbf{3 a}$ and $\mathbf{3 b}$ results in a partial shift to $m / z 29$. This indicates that the $m / z 28$ fragment is a mixture of $\mathrm{CO}$ and $\mathrm{HCNH}$ or $\mathrm{CH}_{2}=\mathrm{N}$, with $\mathrm{CO}$ being the major component. This finding proves that upon electron-transfer, protonated oxazolones do dissociate by elimination of $\mathrm{CO}$, invalidating one of the key arguments in the Haselmann hypothesis $[9]$.

A few more minor features of the NR mass spectra deserve ${ }^{\circ}$ comments. ${ }^{\circ}$ Figure $3 \mathrm{~b}^{\circ}$ and ${ }^{\circ} \mathrm{c}^{\circ}$ show ${ }^{\circ}$ small ${ }^{\circ}$ but conspicuous peaks at $m / z 86$ and 87 , respectively, that have no equivalent in the NR mass spectrum of 3 . We 


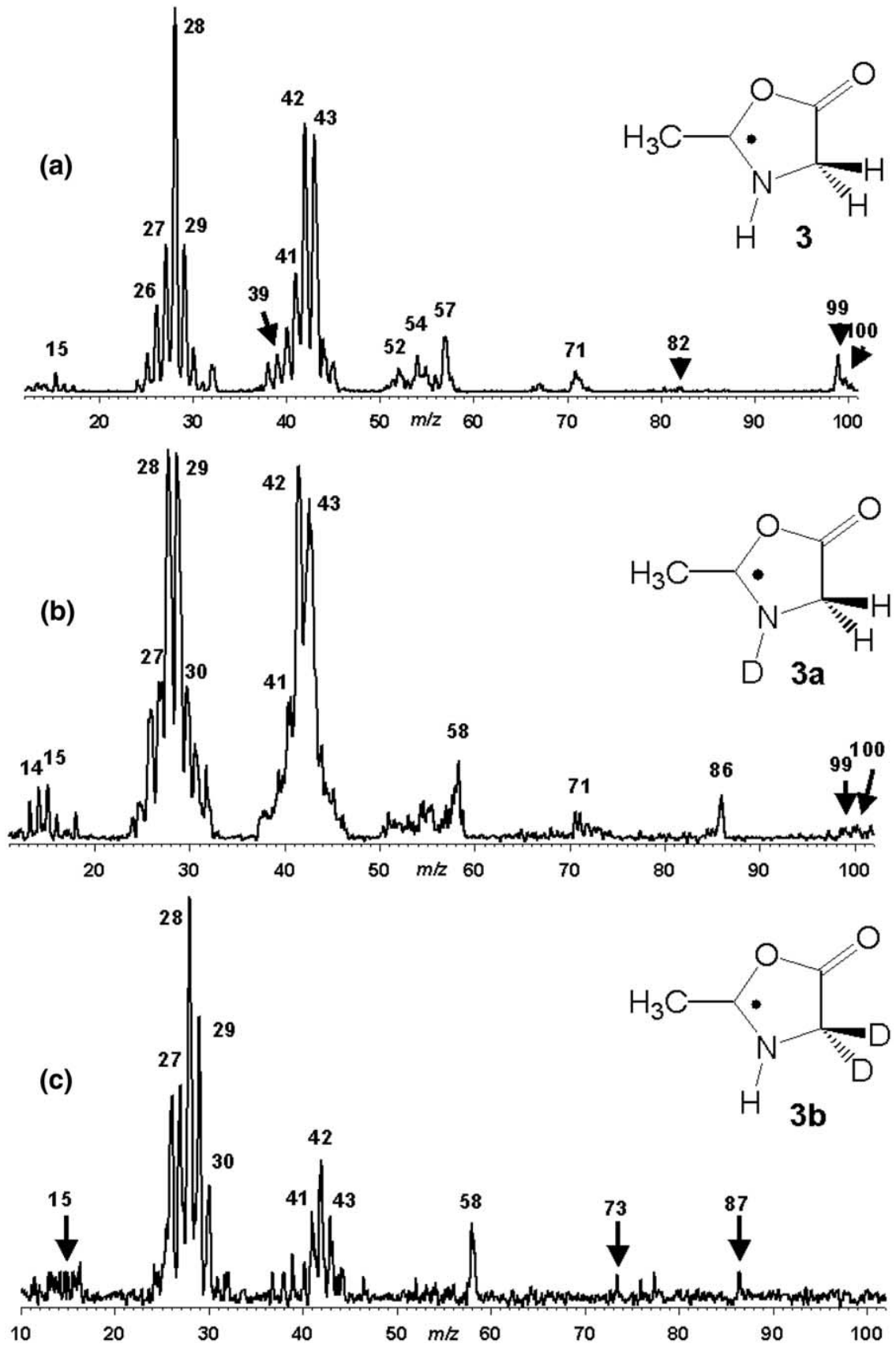

Figure 4. Neutralization $\left(\mathrm{CH}_{3} \mathrm{SSCH}_{3}, 70 \% \mathrm{~T}\right)$ /reionization $\left(\mathrm{O}_{2}, 70 \% \mathrm{~T}\right)$ mass spectra of $(\mathbf{a}) 3^{+},(\mathbf{b}) 3 \mathbf{a}^{+}$, and $(\mathbf{c}) 3 \mathbf{b}^{+}$.

found by careful accurate mass measurements that the samples of $\mathbf{3 a}$ and $\mathbf{3 b}$ contained a trace amount of triethylamine that gave ions at $m / z 101\left(\mathrm{M}^{+}\right)$and $\mathrm{m} / \mathrm{z}$ $102(\mathrm{M}+\mathrm{H})^{+}$amounting to about $5 \%$ of the $\mathrm{C}_{4} \mathrm{H}_{5} \mathrm{DNO}_{2}$ and $\mathrm{C}_{4} \mathrm{H}_{4} \mathrm{D}_{2} \mathrm{NO}_{2}$ peaks from $\mathrm{CI}$ of $3 \mathbf{a}$ and $3 \mathbf{b}$, respectively. It turned out that NR of the triethylamine ions was more efficient than that of $3 \mathbf{a}^{+}, \mathbf{3} \mathbf{b}^{+}$ and gave rise to a very abundant $\mathrm{m} / \mathrm{z} 86$ ion (Supplemental Material, Figure S1a) that contaminated the NR spectra of the labeled oxazolones. However, Figure S1b (Supplemental Material) shows that correcting for the contribution of triethylamine to elim- inate the $m / z 86$ peak did not significantly affect the relative intensities of the other NR fragments from $3 a$.

NR mass spectra of ions $3^{\prime+}$ produced from $\mathrm{N}$ acetylglycine ethyl ester were inconclusive because of mass interferences from dissociations of the adjacent and equally abundant $\mathrm{m} / \mathrm{z} 99$ ions. Because of fragment overlaps, the NR mass spectra of $\mathrm{m} / \mathrm{z} 99$ and $\mathrm{m} / \mathrm{z} 100$ precursor ions contained similar fragments when measured using the linked scan method and did not allow us to draw firm conclusions about the nature of $3^{\prime}$. We note, however, that CAD spectra of $3^{\prime+}$ that were interference free indicated that it and $3^{+}$were identically behaving ion species. 
Table 2. Radical dissociation and transition state energies

\begin{tabular}{|c|c|c|c|c|c|}
\hline \multirow[b]{3}{*}{ Species/reaction } & \multicolumn{5}{|c|}{ Energy $^{\mathrm{ab}}$} \\
\hline & \multirow[b]{2}{*}{$\begin{array}{c}6-31++G(d, p) \\
\text { B3LYP }\end{array}$} & \multicolumn{4}{|c|}{$6-311++G(3 d f, 2 p)$} \\
\hline & & B3LYP & $\mathrm{PMP}^{\mathrm{c}}$ & B3-PMP2 ${ }^{\mathrm{c}}$ & $\operatorname{ccsD}(T)^{c}$ \\
\hline 3 & 0 & 0 & 0 & 0 & 0 \\
\hline $3 \rightarrow 1+\mathrm{H}^{\bullet}$ & 110 & 105 & 72 & 88 & 88 \\
\hline $3 \rightarrow$ TS1 & 119 & 118 & 107 & 113 & 117 \\
\hline $3 \rightarrow 7+\mathrm{H}^{\bullet}$ & 172 & 160 & 137 & 148 & 153 \\
\hline $3 \rightarrow 8+\mathrm{H}^{\bullet}$ & 194 & 178 & 166 & 172 & 186 \\
\hline $3 \rightarrow$ TS2 & 62 & 62 & 83 & 73 & 80 \\
\hline 9 & 19 & -20 & -19 & -19 & -13 \\
\hline 10 & -17 & -18 & -16 & -17 & -10 \\
\hline $3 \rightarrow$ TS3 & 16 & 12 & 23 & 17 & 23 \\
\hline $3 \rightarrow 11+\mathrm{CO}$ & -5 & -14 & -6 & -10 & -10 \\
\hline $3 \rightarrow \mathrm{CO}+\mathrm{CH}_{3} \mathrm{CO}^{\bullet}+\mathrm{HN}=\mathrm{CH}_{2}$ & 127 & 114 & 134 & 124 & 119 \\
\hline $3 \rightarrow \mathrm{CH}_{3} \mathrm{CONH}^{\bullet}+\mathrm{CH}_{2}=\mathrm{C}=\mathrm{O}$ & 107 & 95 & 148 & 121 & 137 \\
\hline $3 \rightarrow \mathrm{CO}+\mathrm{CH}_{3} \mathrm{CON}=\mathrm{CH}_{2}+\mathrm{H}^{\bullet}$ & 205 & 192 & 173 & 183 & 174 \\
\hline 12 & 19 & 16 & 21 & 19 & 22 \\
\hline 13 & 19 & 17 & 27 & 22 & 26 \\
\hline $3 \rightarrow$ TS4 & 130 & 132 & 153 & 142 & 136 \\
\hline $3 \rightarrow$ TS5 & 117 & 113 & 120 & 116 & 126 \\
\hline 14 & 13 & 10 & 17 & 14 & 20 \\
\hline
\end{tabular}

an units of $\mathrm{kJ} \mathrm{mol}^{-1}$.

'Including B3LYP/6-31 ++ G(d,p) zero-point vibrational corrections and referring to $0 \mathrm{~K}$.

'Spin-projected energies.

${ }^{\mathrm{d}}$ From basis set expansion according to eq 4.

\section{Radical Dissociation and Transition State Energies}

To interpret the experimental data, we carried out ab initio calculations of the dissociation and transitionstate energies of 3 and several relevant radical intermediates. The energies discussed in the text are all from ZPVE-corrected CCSD(T) single-point calculations, the energies calculated at the other levels of theory ${ }^{\circ}$ are $^{\circ}$ listed $^{\circ}$ in $^{\circ}$ Table $^{\circ} 2 .^{\circ}$ The $^{\circ}$ optimized $^{\circ}$ radical structures ${ }^{\circ}$ are ${ }^{\circ}$ shown $^{\circ}{ }^{\circ}{ }^{\circ}{ }^{\circ}$ Figure $^{\circ} 5,{ }^{\circ}$ the ${ }^{\circ}$ transition-state structures ${ }^{\circ}$ are ${ }^{\circ}$ in $^{\circ}$ Figure $^{\circ} 6$, ${ }^{\circ}$ and ${ }^{\circ}$ the $e^{\circ}$ main ${ }^{\circ}$ dissociation pathways are visualized in a potential energy diagram $^{\circ}$ in $^{\circ}$ Figure $^{\circ} 7$.

Dissociation of the $\mathrm{N}-3-\mathrm{H}$ bond in 3 requires $88 \mathrm{~kJ}$ $\mathrm{mol}^{-1}$ threshold energy to form 2-methyloxazol-5-one (1). As often observed for heteroatom- $\mathrm{H}$ bond dissociations in heterocyclic radicals, [24d, 24e, 36], the $\mathrm{N}-3-\mathrm{H}$ bond dissociation requires an additional energy in the transition-state, $\mathrm{E}_{\mathrm{TS} 1^{\circ}}={ }^{\circ} 117^{\circ} \mathrm{kJ}^{\circ} \mathrm{mol}^{-1^{\circ}}$ (Figure 7). . Losses $^{\circ}$ of ${ }^{\circ}$ other ${ }^{\circ}$ hydrogen ${ }^{\circ}$ atoms ${ }^{\circ}$ from 3 are ${ }^{\circ}$ substantially more endothermic. For example, a loss of an $\mathrm{H}$ atom from the methyl group forming 2-methylenoxazolin-5-one (7) requires $153 \mathrm{~kJ} \mathrm{~mol}^{-1}$ threshold energy, while a loss of an $\mathrm{H}$ atom from the $\mathrm{C}-4$ methylene requires ${ }^{\circ} 186^{\circ} \mathrm{kJ}^{\circ} \mathrm{mol}^{-1^{\circ}}$ to $^{\circ}$ form ${ }^{\circ} \mathrm{N}$-acetylaminoketene ${ }^{\circ}(8)$ (Table ${ }^{\circ}$ ).

Ring $^{\circ}$ opening ${ }^{\circ}$ by $^{\circ}$ breaking $^{\circ}$ the ${ }^{\circ} \mathrm{O}-1-\mathrm{C}-5^{\circ}$ bond ${ }^{\circ}$ requires the lowest transition-state energy at $\mathrm{E}_{\mathrm{TS2} 2}=80 \mathrm{~kJ}$ $\mathrm{mol}^{-1}$. The open-ring radical 9 is $13 \mathrm{~kJ} \mathrm{~mol}^{-1}$ more stable than 3, making the ring opening exothermic. Radical 9 can undergo a practically thermoneutral rotation about the C-4-C-5 bond to form an anti-rotamer
10. Cleavage of the $\mathrm{C}-4-\mathrm{C}-5$ bond in 9 proceeds through a low-lying transition-state (TS3), $\mathrm{E}_{\mathrm{TS} 3}=23 \mathrm{~kJ}$ mol ${ }^{-1}$ relative to 3 , to form $\mathrm{CO}$ and $\mathrm{CH}_{3} \mathrm{CO}-\mathrm{NH}-\mathrm{CH}_{2}$. (11) at $-10 \mathrm{~kJ} \mathrm{~mol}^{-1}$ relative to 3 . Radical 11 can further dissociate by several low-energy pathways, e.g., by loss of $\mathrm{H}, \mathrm{CH}_{2^{\circ}}={ }^{\circ} \mathrm{C}^{\circ}={ }^{\circ} \mathrm{O}$, and ${ }^{\circ} \mathrm{CH}_{2^{\circ}}={ }^{\circ} \mathrm{NH}^{\circ}\left(\right.$ Table $\left.{ }^{\circ} 2\right)$.

The alternative ring opening in 3 by cleavage of the $\mathrm{N}-3-\mathrm{C}-4$ bond is slightly endothermic when forming open-ring intermediates $\mathbf{1 2}$ and its rotamer 13. The TS for this ring opening is at $\mathrm{E}_{\mathrm{TS} 4^{\circ}} \approx{ }^{\circ} 136^{\circ} \mathrm{kJ}^{\circ} \mathrm{mol}^{-1^{\circ}}$ (Table?) which is substantially higher than for the ring opening at O-1-C-5. We note that locating TS4 with B3LYP optimizations was difficult and not fully satisfactory, as the potential energy surface showed a cusp at $d(\mathrm{~N}-3-$ C-4) $\approx 1.950 \AA$ (Supplementary Material section, Figure S2). Thus, the TS4 energy from the present single-point calculations is rather tentative. Multireference CASSCF calculations including large active space (7 electrons, 12 orbitals) showed negligible mixing of other states at and near the TS4 geometry. The electron occupancies were as follows: singly-occupied molecular orbital (SOMO, 27): 1.00, doubly-occupied MO26: $1.92, \mathrm{MO} 25: 1.97$, and MO24: 1.98, virtual orbitals MO28: 0.017, MO29: 0.0003, MO30: 0.0008, MO31: 0.022, MO32: 0.001, MO33: 0.005, MO34: 0.005, and MO35: 0.08. Hence, the problem with locating the TS was not due to an inadequate singledeterminant wave function.

The unfavorable $\mathrm{N}-3-\mathrm{C}-4$ bond cleavage in 3 is probably $^{\circ}$ due $^{\circ}$ to ${ }^{\circ}$ stereoelectronic $^{\circ}$ effects $^{\circ}$ [37]. ${ }^{\circ}$ The oxazolone ring in $\mathbf{3}$ has a rigid near-planar conformation enforced by two sp ${ }^{2}$ carbon atoms (C-2 and C-5). 


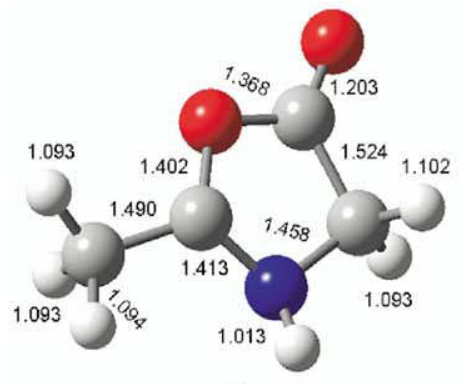

3

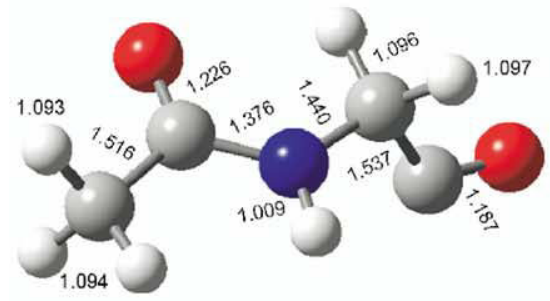

10

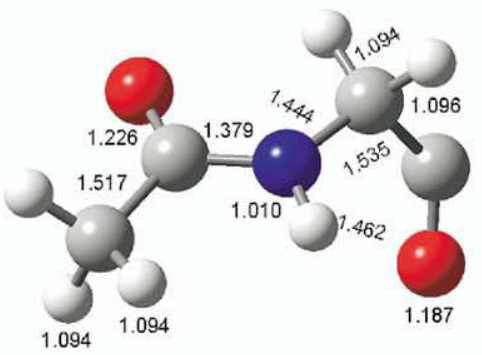

9

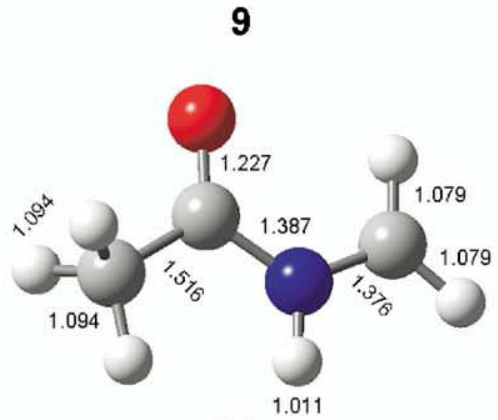

11
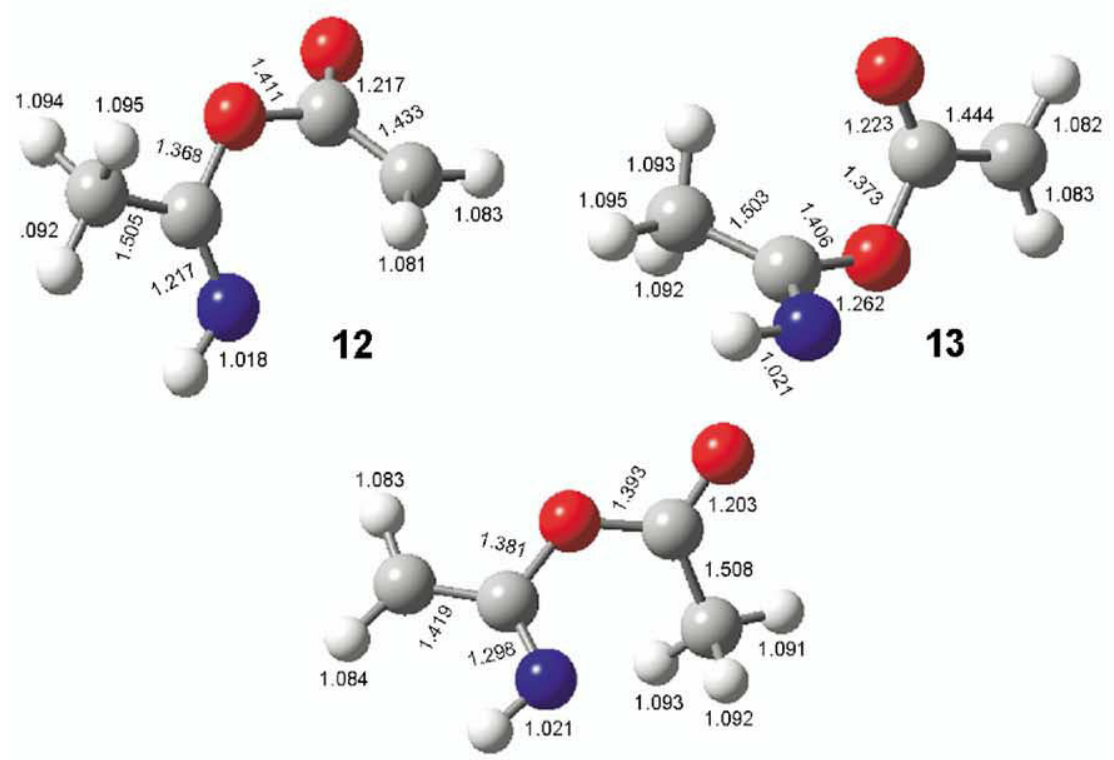

14

Figure 5. B3LYP/6-31 $++G(d, p)$ optimized structures of radicals 3, 9-14. Bond lengths in angstroms.

In the course of N-3-C-4 bond dissociation the C-4 methylene group must rotate to assume the lowest energy conformation which is co-planar with the $\mathrm{O}-1-\mathrm{C}-5=\mathrm{O}-6$ group in the product $\mathbf{1 2}$ to allow electron delocalization over the $\mathrm{CH}_{2}-\mathrm{C}(=\mathrm{O})-$ $\mathrm{O}-\mathrm{C}=\mathrm{N}$ system. However, such a rotation cannot take place in an early transition-state because of the ring rigidity, and the impaired electron delocalization contributes to the increased TS4 energy. Further reactions of intermediates $\mathbf{1 2}$ and $\mathbf{1 3}$ may involve elimination of ketene or an isomerization by intramolecular hydrogen transfer through TS5 to form radi- cal 14, followed by loss of $\mathrm{CH}_{3} \mathrm{CO}$. However, products of these dissociation pathways are not observed in the NR mass spectra of 3, as established by deuterium labeling (vide supra), and thus must be kinetically disfavored.

In summarizing this part, the calculations indicate that a ring opening followed by $\mathrm{CO}$ expulsion is the lowest-energy dissociation of oxazolone radical 3 . The radical intermediates produced by $\mathrm{CO}$ loss can dissociate further to form $\mathrm{CH}_{3} \mathrm{CO}, \mathrm{CH}_{2}=\mathrm{NH}$, and other low-mass fragments. These findings are in line with the experimental data from NR mass spectra. 

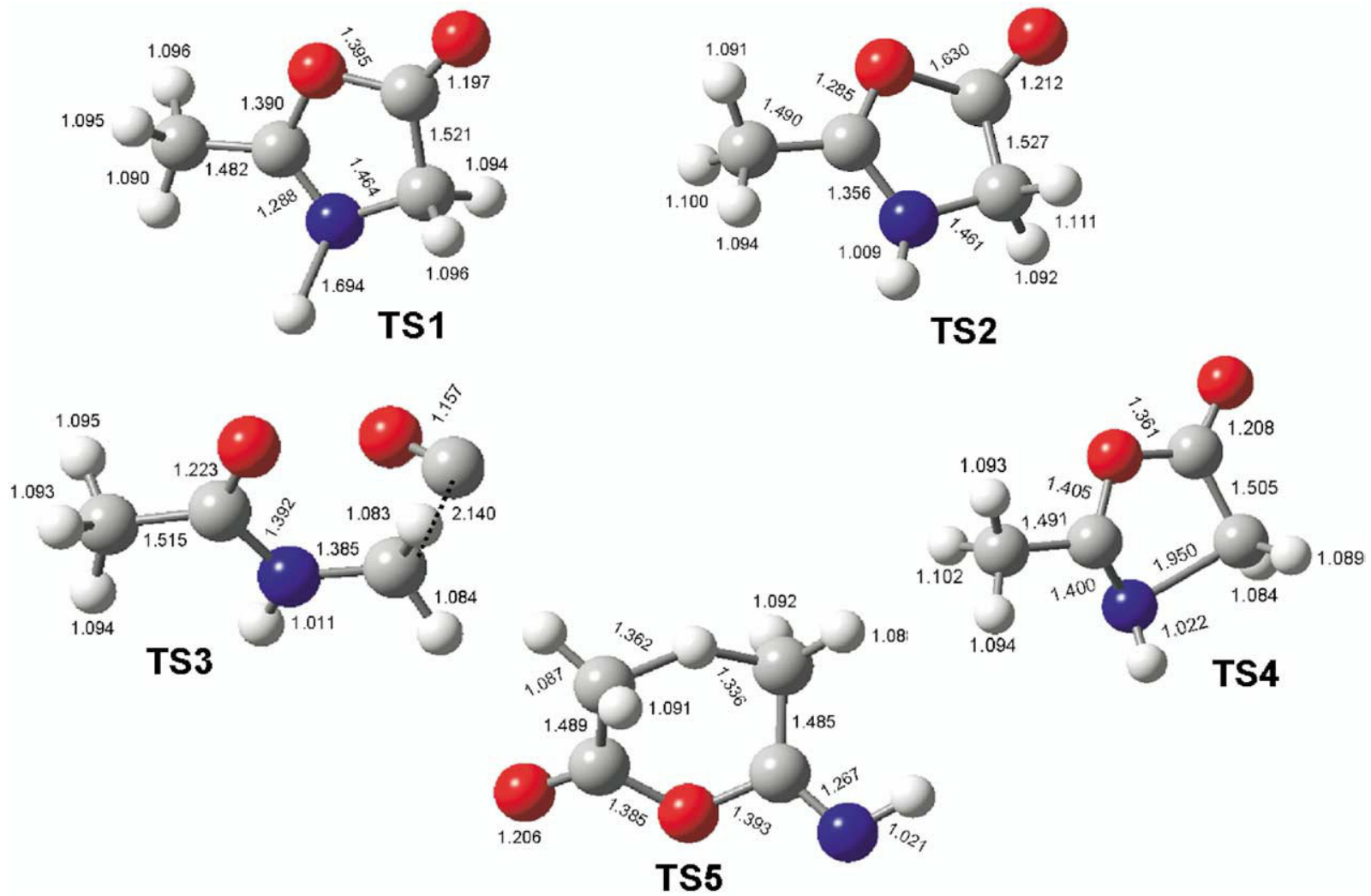

Figure 6. B3LYP/6-31 ++ G(d,p) optimized structures of transition states for radical isomerizations and dissociations. Bond lengths in angstroms.

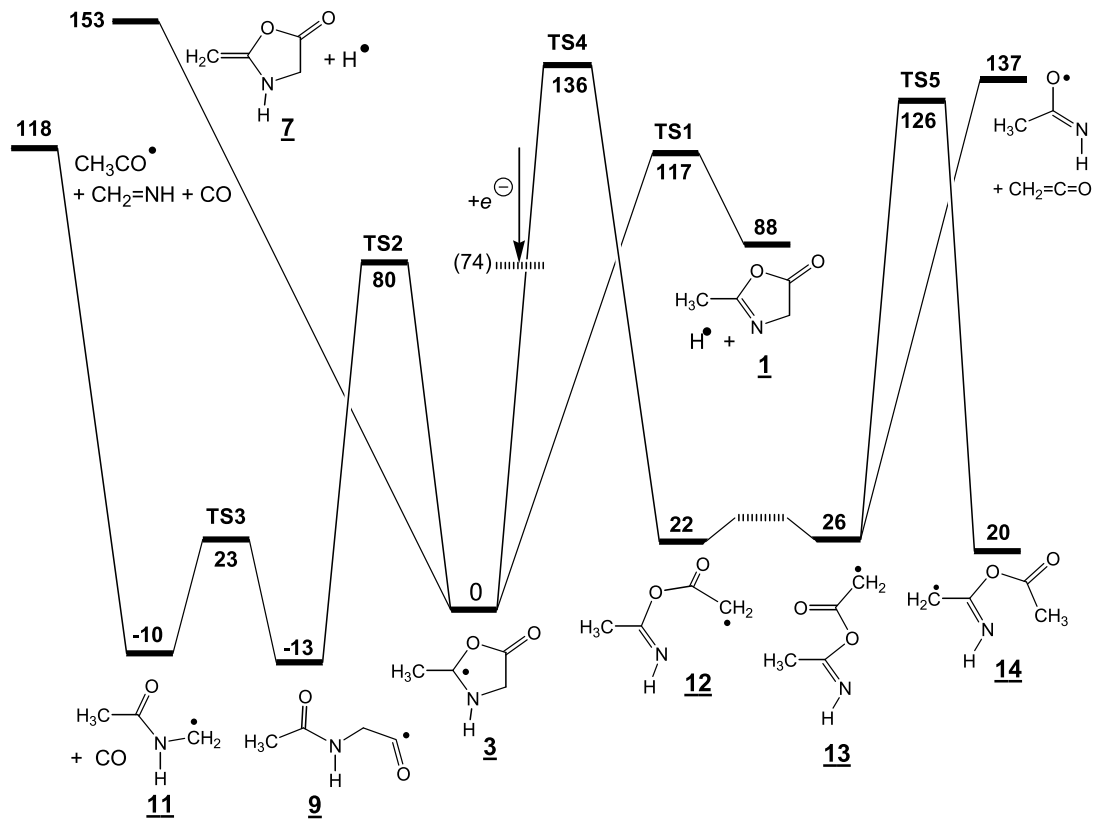

Figure 7. Potential energy diagram for dissociations of 3 . The energies are from single-point $\operatorname{CCSD}(\mathrm{T}) / 6-311++\mathrm{G}(3 \mathrm{df}, 2 \mathrm{p})$ calculations and include B3LYP/6-31 ++ G(d,p) ZPVE corrections. 


\section{Franck-Condon Effects}

The NR mass spectra indicate extensive dissociation of 3 despite the fact that the radical is calculated to be inherently stable and reside in a $80 \mathrm{~kJ} \mathrm{~mol}^{-1}$ deep potential energy minimum. The reason for the rapid dissociation is the internal energy that the radicals receive upon collisional electron-transfer at $\mathrm{keV}$ kinetic energies ${ }^{\circ}[38] .{ }^{\circ}$ Under ${ }^{\circ}$ these ${ }^{\circ}$ conditions, ${ }^{\circ}$ the ${ }^{\circ}$ radical ${ }^{\circ}$ internal energy consists of the precursor ion internal energy $\left(E_{\text {ion }}\right)$, the electronic excitation $\left(\mathrm{E}_{\text {exc }}\right)$, and the excitation due to Franck-Condon effects $\left(\mathrm{E}_{\mathrm{FC}}\right)^{\circ}\left[39,{ }^{\circ} 40\right] .{ }^{\circ} \mathrm{E}_{\mathrm{FC}}$ ensue from a mismatch between the equilibrium geometry of the precursor cation and that of the radical, such that vertical electron-transfer results in vibrational excitation In the product $\left.{ }^{9} 41\right]$. The ${ }^{\circ}$ optimized ${ }^{\circ}$ geometries ${ }^{\circ}$ of $^{\circ}{ }^{+}$ and 3 show major differences in the lengths of the $\mathrm{O}-1-\mathrm{C}-2, \mathrm{C}-2-\mathrm{N}-3, \mathrm{O}-1-\mathrm{C}-5$, and $\mathrm{C}-5-\mathrm{O}-6$ bonds (Figure $\left.{ }^{\circ} 5\right)^{\circ} .^{\circ}$ In $^{\circ}$ addition, ${ }^{\circ} \mathrm{N}-3^{\circ}$ which ${ }^{\circ}$ is ${ }^{\circ}$ planar ${ }^{\circ}$ in ${ }^{\circ} 3^{+}{ }^{\circ}$ is pyramidized in 3 . These geometry differences can be expected to cause excitation of several stretching and bending vibrational modes in vertically produced 3 , e.g., the $\nu_{\text {asym }}(\mathrm{C}-2-\mathrm{O}-1-\mathrm{C}-5)$ at $892 \mathrm{~cm}^{-1}, \nu(\mathrm{O}-1-\mathrm{C}-5)$ at $1110 \mathrm{~cm}^{-1}, \nu(\mathrm{C}-3-\mathrm{N}-3)$ at $1267 \mathrm{~cm}^{-1}$, and $\nu(\mathrm{C}-5-$ O-6) at $1799 \mathrm{~cm}^{-1}$. The overall vibrational excitation in 3 due to Franck-Condon effects is calculated at $74 \mathrm{~kJ}$

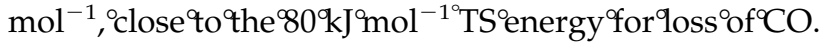

\section{Dissociation Kinetics and Branching Ratios}

The transition-state energies were further used for RRKM calculations of unimolecular rate constants for dissociations ${ }^{\circ}$ of ${ }^{\circ} 3{ }^{\circ}$ Figure ${ }^{\circ}{ }^{\circ}$ shows ${ }^{\circ}$ that ${ }^{\circ}$ the ${ }^{\circ}$ rate ${ }^{\circ}$ constant for the $\mathrm{O}-1-\mathrm{C}-5$ bond break reaches $k=1 / t=2 \times 10^{5}$ $\mathrm{s}^{-1}$ within $4 \mathrm{~kJ} \mathrm{~mol}^{-1}$ of $\mathrm{E}_{\mathrm{TS} 2}$, where $t$ is the experimental time scale for radical dissociations $(5.1 \mu \mathrm{s})$. This indicates that this dissociation of $\mathbf{3}$ is subject to a negligible ${ }^{\circ}$ kinetic $^{\circ}$ shift $^{\circ}$ in $^{\circ}$ our $^{\circ}$ measurements ${ }^{\circ}[42]^{\circ}{ }^{\circ}$ The consecutive dissociation by $\mathrm{CO}$ loss from intermediate 9 is very fast $\left(\mathrm{k}>10^{11} \mathrm{~s}^{-1}\right)$ at excitations achieved by crossing TS2 in the preceding step. The reverse ring closure in 9 is 4 to 5 orders of magnitude slower than the loss of $\mathrm{CO}$ and does not affect the dissociation kinetics. The loss of $\mathrm{H}$ from $\mathrm{N}-3$ shows a small kinetic shift of $20 \mathrm{~kJ} \mathrm{~mol}{ }^{-1}$. However, the loss of $\mathrm{H}$ from 3 is slower than the ring opening over the entire range of relevant internal energies. This is depicted in breakdown diagrams that were plotted using RRKM rate constants calculated at two levels of theory for dissociations ${ }^{\circ}$ occurring ${ }^{\circ}$ on $^{\circ}$ the ${ }^{\circ}$ experimental ${ }^{\circ}$ time ${ }^{\circ}$ scale $^{\circ}$ (Figure

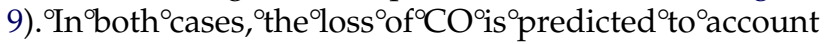
for $>90 \%$ of dissociation over a broad range of internal energies.

A comparison of the calculated branching ratios with the product ion relative intensities in the NR mass spectra is not straightforward for several reasons. First, the ion intensities are affected by the cross sections for collisional reionization that tend to discriminate ${ }^{\circ}$ against ${ }^{\circ}$ small $^{\circ}$ fragments ${ }^{\circ}[43] .{ }^{\circ}$ Second, ${ }^{\circ}$ radi-

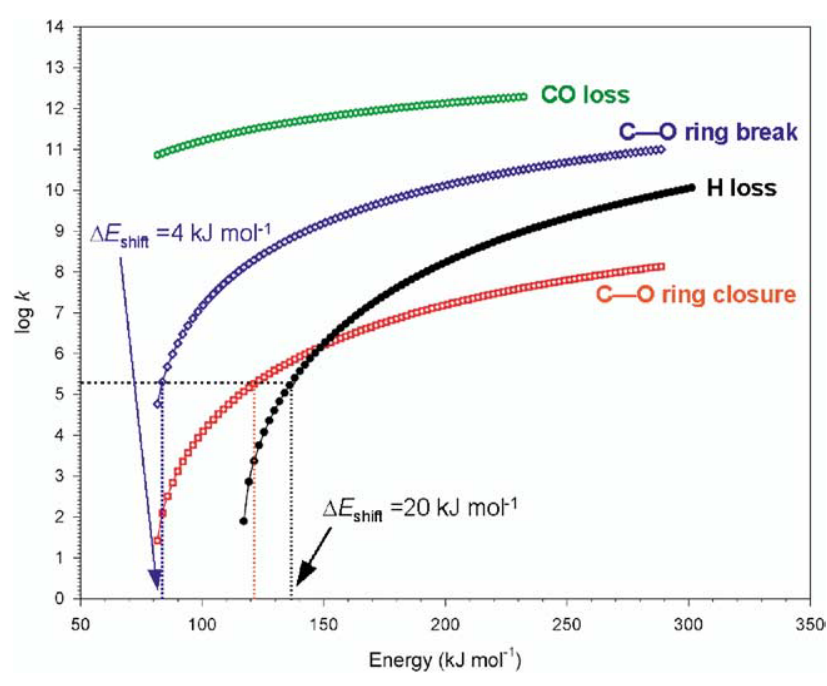

Figure 8. RRKM rate constants for unimolecular dissociations of 3. $\Delta E_{\text {shift }}$ denotes the energy for the dissociation to occur with $k=$ $1 / t$ on the experimental time scale $t$ (the kinetic shift).

cal intermediates often undergo consecutive dissociations that result in convergent products formed by two or more dissociation pathways. Finally, the branching ratios from RRKM calculations usually describe dissociations on the potential energy surface of the ground electronic state, while NR mass spectra display dissociations from all electronic states accessed ${ }^{\circ}$ by $^{\circ}{ }^{\circ}$ collisional ${ }^{\circ}$ electron-transfer ${ }^{\circ}[44] .{ }^{\circ}$ For ${ }^{\circ}$ these reasons, it is difficult to compare the extent of $\mathrm{CO}$ elimination in the NR mass spectra to the branching ratios from RRKM calculations.

\section{Ionization Energies and Excited Electronic States}

The dissociations observed in the NR mass spectra may originate from any of the electronic states accessed by vertical ${ }^{\circ}$ electron-transfer. ${ }^{\circ}$ Figure ${ }^{\circ} 10^{\circ}$ shows ${ }^{\circ}$ the ${ }^{\circ}$ recombination and ionization energies relevant to 3 and $3^{+}$and the three lowest excited electronic states in the radical. The adiabatic ionization energy of $3\left(\mathrm{IE}_{\text {adiab }}=5.48\right.$ and $5.51 \mathrm{eV}$ by $\operatorname{CCSD}(\mathrm{T})$ and B3-PMP2, respectively) is substantially different from both the vertical ionization energy, $\mathrm{IE}_{\mathrm{vert}}=6.94 \mathrm{eV}$, and the vertical recombination energy of $3^{+}, \mathrm{RE}_{\mathrm{vert}}=4.70 \mathrm{eV}$. This indicates large Franck-Condon effects in both vertical neutralization and reionization. The first three electronically excited states of $3(A-C)$ are within $1.80-2.62 \mathrm{eV}(176-253 \mathrm{~kJ}$ $\mathrm{mol}^{-1}$ ) of the ground state $(X)$. If populated by collisional electron-transfer, these states can nonradiatively convert the electronic excitation energy into the vibrational energy of the $\boldsymbol{X}$ state of $\mathbf{3}$ and drive its primary and consecutive dissociations. Thus, involvement of even the lowest excited electronic states may explain the extensive dissociations of $\mathbf{3}$ upon collisional electrontransfer. 

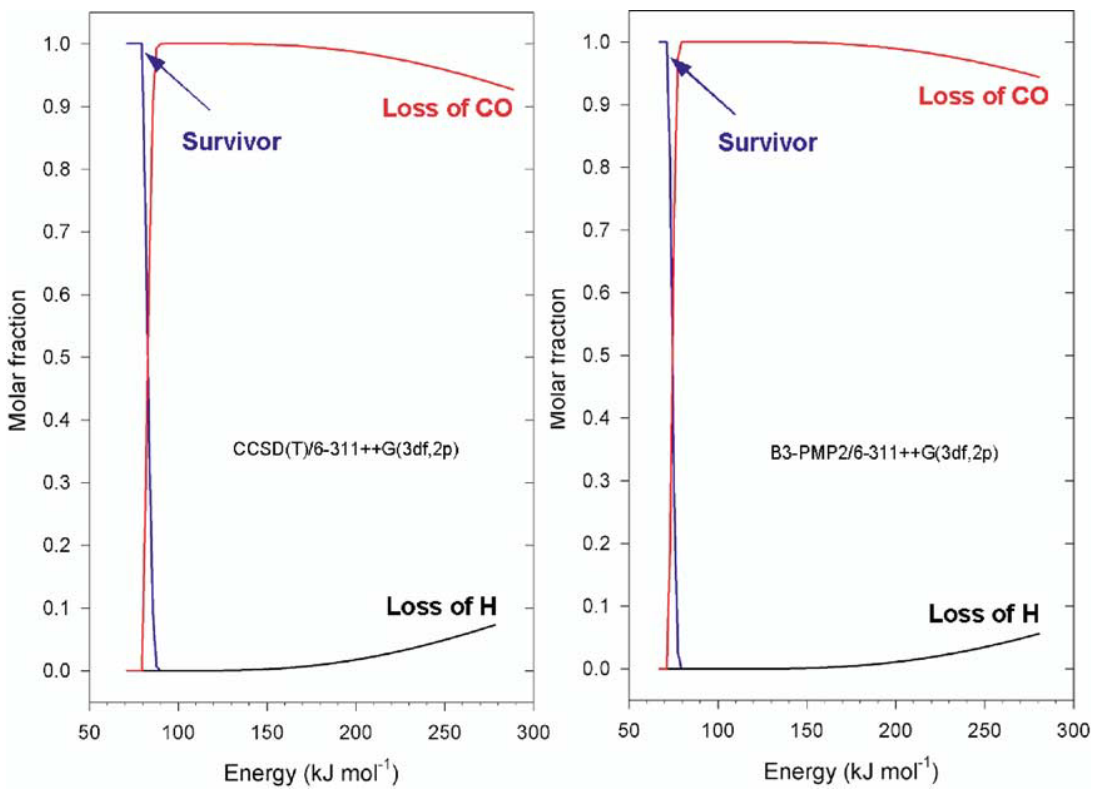

Figure 9. Calculated branching ratios for loss of $\mathrm{H}-3$ and $\mathrm{O}-1-\mathrm{C}-5$ bond cleavage in 3 . Left panel: From CCSD(T)/6-311 ++ G(3df,3p) TS energies. Right panel: From B3-PMP2/6-311 ++ G(3df,2p) TS energies.

\section{Discussion}

The results of the present NR mass spectrometric measurements and energy and RRKM calculations are now used to discuss the properties of oxazolone radicals in connection with electron capture dissociation of $\boldsymbol{b}$-type ions. In their argumentation, Haselmann et al. presumed that oxazolone radicals should preferentially lose ${ }^{\circ}$ the ${ }^{\circ}$ amide ${ }^{\circ}$ ydrogen ${ }^{\circ}$ atom, ${ }^{\text {nnot }}{ }^{\circ} \mathrm{CO}^{\circ}[9]$. The ${ }^{\circ}$ present data clearly invalidate this argument by showing that loss of $\mathrm{CO}$ is in fact the dominating dissociation of oxazolone radicals. Another argument by Haselmann et
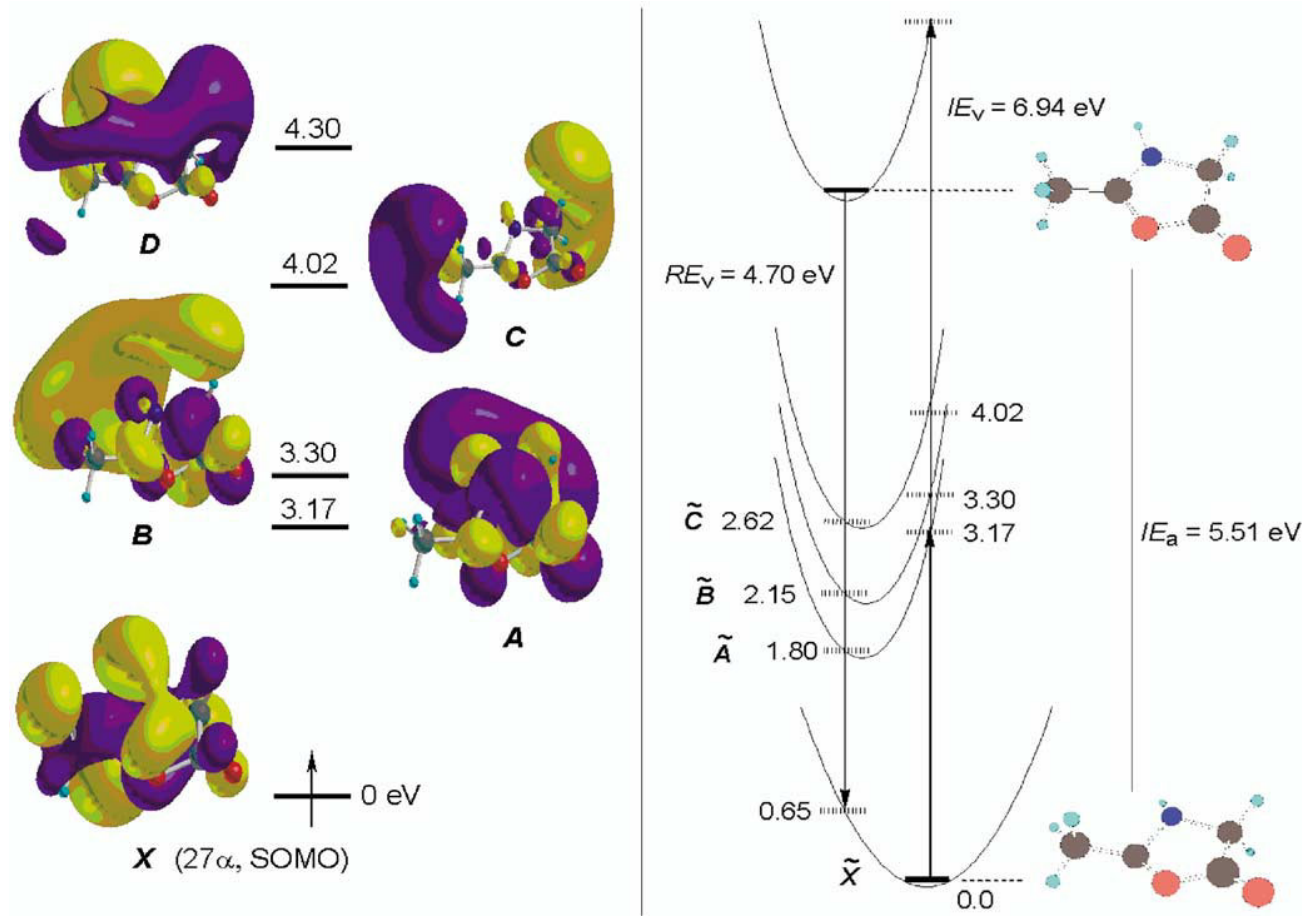

Figure 10. Left panel: Molecular orbitals for the ground $(X)$ and $A-D$ doublet excited states in 3 . Right panel: Ionization and excitation energies in 3 and recombination energies in $3^{+}$. The vertical excitation energies are from TD-B3LYP/6-311 ++ G(2d,p) single-point calculations. 
al. was that electron capture would not occur in a protonated oxazolone residue to drive the dissociation. The present data show that protonated oxazolones have recombination energies that are greater than those of protonated basic amino acid residues, e.g., guanidinium in $^{\circ} \mathrm{Arg}^{\circ}\left(3.53-3.56^{\circ} \mathrm{eV}\right)^{\circ}[45]^{\circ},{ }^{\circ}$ ammonium ${ }^{\circ}{ }^{\circ} \mathrm{Lys}^{\circ}(3.15-4.20$ $\mathrm{eV})^{\circ}[46]^{\circ}$ and $^{\circ}$ imidazolium $^{\circ}$ in $^{\circ}$ His $^{\circ}\left(3.55-3.87^{\circ} \mathrm{eV}\right)^{\circ}[47]$ There is a growing evidence from recent studies that ECD fragmentation of multiply charged peptides occurs at or near the charge sites of highest recombination energies[48]. ${ }^{\circ}$ According ${ }^{\circ}$ to ${ }^{\circ}$ this ${ }^{\circ}$ empirical ${ }^{\circ}$ rule, ${ }^{\circ}$ a protonated oxazolone residue in a doubly charged $\boldsymbol{b}$-ion should be the primary site of electron capture and the ensuing dissociation. Hence, both the electronic properties and the chemistry of oxazolone radicals, as revealed by the present study, are in keeping with the loss of $\mathrm{CO}$ upon ECD of $\boldsymbol{b}$-ions.

\section{Conclusions}

The present experimental and computational results show that oxazolone radicals formed by collisional electron-transfer undergo facile dissociation. The major dissociation pathway is exothermic ring opening by cleavage of the weak $\mathrm{O}-1-\mathrm{C}-5$ bond followed by elimination of $\mathrm{CO}$ and $\mathrm{CH}_{3} \mathrm{CO}$. Dissociations by $\mathrm{H}$ atom loss are less abundant and involve hydrogen atoms from both the ring and side-chain. These results lead us to conclude that oxazolone radicals are perfectly acceptable as intermediates of CO loss from $\boldsymbol{b}$-type peptide ions in electron capture dissociation. By refuting the arguments to the contrary, the present study supports cyclic oxazolone structures for gas-phase $\boldsymbol{b}$-ions from peptides.

\section{Acknowledgments}

The authors gratefully acknowledge support of this research by the National Science Foundation (grants CHE-0349595 for experiments and CHE-0342956 for computations). The Department of Chemistry Computational Facility was supported jointly by the NSF and University of Washington. Thanks are due to Dr. Martin Sadilek for assistance with CAD spectra measurements. The Jeol HX-110 mass spectrometer was a generous donation from the former Seattle Biomembrane Institute by courtesy of Professor S. Hakomori.

\section{References}

1. (a) Roepstorff, P.; Fohlmann, J. Proposal for a common nomenclature for sequence ions in mass spectra of peptides. Biomed. Mass Spectrom. 1984, 11, 601. (b) Biemann, K. Contributions of mass spectrometry to peptide and protein structure. Biomed. Environ. Mass Spectrom. 1988, 16, 99-111.

2. Papayannopoulos, I. A. The interpretation of collision-induced dissociation tandem mass spectra of peptides. Mass Spectrom. Rev. 1995, 14, 49-73.

3. Paizs, B.; Suhai, S. Fragmentation pathways of protonated peptides. Mass Spectrom. Rev. 2005, 24, 508-548.

4. Yalcin, T.; Khouw, C.; Csizmadia, I. G.; Peterson, M. R.; Harrison, A. G. Why are b ions stable species in peptide spectra? J. Am. Soc. Mass Spectrom. 1995, 6, 1165-1174.
5. Rodriquez, C. F.; Shoeib, T.; Chu, I. K.; Siu, K. W. M.; Hopkinson, A. C. Comparison between protonation, lithiation, and argentation of 5-oxazolones: A study of a key intermediate in gas-phase peptide sequencing. J. Phys. Chem. A 2000, 104, 5335-5342.

6. Paizs, B.; Szlavik, Z.; Lendvay, G.; Vekey, K.; Suhai, S. Formation of $\mathrm{a}_{2}{ }^{+}$ions of protonated peptides. An ab initio study. Rapid Commun. Mass Spectrom. 2000, 14, 746-755.

7. (a) Csonka, I. P.; Paizs, B.; Lendvay, G.; Suhai, S. Proton mobility and main fragmentation pathways of protonated lysylglycine. Rapid Commun. Mass Spectrom. 2001, 15, 14571472. (b) Yalcin, T.; Harrison, A. G. Ion chemistry of protonated lysine derivatives. J. Mass Spectrom. 1996, 31, 1237-1243. (c) Farrugia, J. M.; O'Hair, R. A. J.; Reid, G. E. Do all b $b_{2}$ ions have oxazolone structures? Multistage mass spectrometry and ab initio studies on protonated $\mathrm{N}$-acylamino acid methyl ester model systems. Int. J. Mass Spectrom. 2001, 210/211, 71-87.

8. Nold, M. J.; Wesdemiotis, C.; Yalcin, T.; Harrison, A. G. Amide bond dissociation in protonated peptides. Structures of the $\mathrm{N}$-terminal ionic and neutral fragments. Int. J. Mass Spectrom. Ion Processes 1997, 164, 137-153.

9. Haselmann, K. F.; Budnik, B. A.; Zubarev, R. A. Electron capture dissociation of $\mathrm{b}^{2+}$ peptide fragments reveals the presence of the acylium ion structure. Rapid Commun. Mass Spectrom. 2000, 14, 2242-2246.

10. (a) Danis, P. O.; Wesdemiotis, C.; McLafferty, F. W. Neutralization-reionization mass spectrometry (NRMS). J. Am. Chem. Soc. 1983, 105, 7454-7456. (b) Burgers, P. C.; Holmes, J. L.; Mommers, A. A.; Terlouw, J. K. Neutral products of ion fragmentations: $\mathrm{HCN}$ and HNC identified by collisionally induced dissociative ionization. Chem. Phys. Lett. 1983, 102, 1-3.

11. Holmes, J. L. The neutralization of organic cations. Mass Spectrom. Rev. 1989, 8, 513-539.

12. Tureček, F. The modern mass spectrometer. A chemical laboratory for unstable neutral species. Org. Mass Spectrom. 1992, 27, 1087-1097.

13. (a) Goldberg, N.; Schwarz, H. Neutralization-reionization mass spectrometry. A powerful laboratory to generate and probe elusive neutral molecules. Acc. Chem. Res. 1994, 27, 347-352. (b) Schalley, C. A.; Hornung, G.; Schröder, D.; Schwarz, H. Mass spectrometric approaches to the reactivity of transient neutrals. Chem. Soc. Rev. 1998, 27, 91-104. (c) Tureček, F. Transient intermediates of chemical reactions by neutralization-reionization mass spectrometry. Top. Curr. Chem. 2003, 225, 77-129.

14. (a) Sadilek, M.; Tureček, F. Probing hypervalent radicals by neutralization-laser photoionization mass spectrometry. $J$. Phys. Chem. 1996, 100, 9610-9614. (b) Polašek, M.; Tureček, F. Nitromethyl radical, cation, and anion. A neutralization and electron photodetachment-reionization mass spectrometric and ab initio computational study of $\left[\mathrm{C}, \mathrm{H}_{2}, \mathrm{~N}, \mathrm{O}_{2}\right]$ isomers. $J$. Phys. Chem. A 2001, 105, 1371-1382. (c) Frank, A. J.; Tureček, F. Methylsulfonyl and methoxysulfinyl radicals and cations in the gas phase. A variable-time and photoexcitation neutralization-reionization and ab initio/RRKM study. J. Phys. Chem. A 1999, 103, 5348-5361.

15. (a) Kuhns, D. W.; Tran, T. B.; Shaffer, S. A.; Tureček, F. Methylthiomethyl radical. A variable-time neutralizationreionization and ab initio study. J. Phys. Chem. 1994, 98, 4845-4853. (b) Kuhns, D. W.; Tureček, F. Unimolecular neutral and ion kinetics by variable-time neutralization-reionization mass spectrometry. Org. Mass Spectrom. 1994, 29, 463-469. (c) Polašek, M.; Tureček, F. Direct observation of hydrogen atom adducts to nitromethane and methyl nitrite. A variable-time neutralization-reionization mass spectrometric and ab initio/ RRKM study. J. Phys. Chem. A 1999, 103, 9241-9251. (d) 
Sadilek, M.; Tureček, F. Dissociations of gas-phase $\mathrm{CHClF}$ and $\mathrm{CHCl}_{2}$ radicals and cations following collisional electron transfer. A variable-time neutralization-reionization and ab initio study. J. Phys. Chem. 1996, 100, 224-232.

16. Gilbert, R. G.; Smith, S. C. Theory of unimolecular and recombination reactions; Blackwell: Oxford, 1990; pp 15-51

17. Kumar, P.; Mishra, H.; Mukerjee, A. K. Condensation of 2-substituted 5-oxo-4,5-dihydro-1,3-oxazoles with imines and their corresponding carbonyl compounds. Synthesis 1980, 836839.

18. Wieland, T.; Müller, R.; Niemann, E.; Birkofer, L.; Schöberl, A.; Wagner, A.; Söll, H. Stickstoffverbindungen III. Aminosäuren und ihre Derivate. In Methoden der Organischen Chemie (Houben-Weyl); Müller, E., Ed.; Georg Thieme Verlag: Stuttgart, 1958; pp 340-341.

19. Tureček, F.; Gu, M.; Shaffer, S. A. Novel tandem quadrupole acceleration-deceleration mass spectrometer for neutralization-reionization studies. J. Am. Soc. Mass Spectrom. 1992, 3, 493-501.

20. Frisch, M. J.; Trucks, G. W.; Schlegel, H. B.; Scuseria, G. E.; Robb, M. A.; Cheeseman, J. R.; Montgomery, J. A., Jr.; Vreven, T.; Kudin, K. N.; Burant, J. C.; Millam, J. M.; Iyengar, S. S.; Tomasi, J.; Barone, V.; Mennucci, B.; Cossi, M.; Scalmani, G.; Rega, N.; Petersson, G. A.; Nakatsuji, H.; Hada, M.; Ehara, M.; Toyota, K.; Fukuda, R.; Hasegawa, J.; Ishida, M.; Nakajima, T.; Honda, Y.; Kitao, O.; Nakai, H.; Klene, M.; Li, X.; Knox, J. E.; Hratchian, H. P.; Cross, J. B.; Adamo, C.; Jaramillo, J.; Gomperts, R.; Stratmann, R. E.; Yazyev, O.; Austin, A. J.; Cammi, R.; Pomelli, C.; Ochterski, J. W.; Ayala, P. Y.; Morokuma, K.; Voth, G. A.; Salvador, P.; Dannenberg, J. J.; Zakrzewski, V. G.; Dapprich, S.; Daniels, A. D.; Strain, M. C.; Farkas, O.; Malick, D. K.; Rabuck, A. D.; Raghavachari, K.; Foresman, J. B.; Ortiz, J. V.; Cui, Q.; Baboul, A. G.; Clifford, S.; Cioslowski, J.; Stefanov, B. B.; Liu, G.; Liashenko, A.; Piskorz, P.; Komaromi, I.; Martin, R. L.; Fox, D. J.; Keith, T.; Al-Laham, M. A.; Peng, C. Y.; Nanayakkara, A.; Challacombe, M.; Gill, P. M. W.; Johnson, B.; Chen, W.; Wong, M. W.; Gonzalez, C.; Pople, J. A. Gaussian 03, Revision B.05; Gaussian, Inc.: Pittsburgh, PA, 2003.

21. (a) Becke, A. D. A New mixing of Hartree-Fock and localdensity-runcional theories. J. Chem. Phys. 1993, 98, 1372-1377. (b) Becke, A. D. Density functional thermochemistry. III. The role of exact exchange. J. Chem. Phys. 1993, 98, 5648-5652. (c) Stephens, P. J.; Devlin, F. J.; Chabalowski, C. F.; Frisch, M. J. $\mathrm{Ab}$ Initio calculation of vibrational absorption and circular dichroism spectra using density functional force fields. J. Phys. Chem. 1994, 98, 11623-11627.

22. Møller, C.; Plesset, M. S. Note on an approximation treatment for nano-electron systems. Phys. Rev. 1934, 46, 618-622.

23. (a) Schlegel, H. B. Potential energy curves using unrestricted Moeller-Plesset perturbation theory with spin annihilation. J. Chem. Phys. 1986, 84, 4530-4534. (b) Mayer, I. The spinprojected extended Hartree-Fock method. Adv. Quantum Chem. 1980, 12, 189-262.

24. (a) Tureček F. Proton affinity of dimethyl sulfoxide and relative stabilities of $\mathrm{C}_{2} \mathrm{H}_{6} \mathrm{OS}$ molecules and $\mathrm{C}_{2} \mathrm{H}_{7} \mathrm{OS}^{+}$ions. A comparative G2(MP2) ab initio and density functional theory study. J. Phys. Chem. A 1998, 102, 4703-4713. (b) Tureček, F.; Wolken, J. K. Dissociation energies and kinetics of aminopyrimidinium radicals by ab initio and density functional theory. J. Phys. Chem. A 1999, 103, 1905-1912. (c) Tureček, F.; Wolken, J. K.; Sadilek, M. Distinction of isomeric pyridyl cations and radicals by neutralization-reionization mass spectrometry, $a b$ initio, and density functional theory calculations. Eur. Mass Spectrom. 1998, 4, 321-332. (d) Wolken, J. K.; Tureček, F. Heterocyclic radicals in the gas phase. An experimental and computational study of 3-hydroxypyridinium radicals and cations. J. Am. Chem. Soc. 1999, 121, 6010-6018. (e) Wolken,
J. K.; Tureček, F. Modeling nucleobase radicals in the gas phase. Experimental and computational study of 2-hydroxypyridinium and 2(1H)-pyridone radicals. J. Phys. Chem. A 1999, 103, 6268-6281. (f) Tureček, F.; Carpenter, F. H. Glycine radicals in the gas phase. J. Chem. Soc. Perkin Trans. 2 1999, 2315-2323. (g) Polašek, M.; Tureček, F. Hydrogen atom adducts to nitrobenzene: Formation of the phenylnitronic radical in the gas phase and energetics of Wheland intermediates. J. Am. Chem. Soc. 2000, 122, 9511-9524.

25. (a) Rablen, P. R. Is the acetate Anion stabilized by resonance or electrostatics? A systematic structural comparison. J. Am. Chem. Soc. 2000, 122, 357-368. (b) Rablen, P. R.; Bentrup, K. H. Are the enolates of amides and esters stabilized by electrostatics? J. Am. Chem. Soc. 2003, 125, 2142-2147.

26. Č́ížek. H.; Paldus, J.; Šroubková, L. Cluster expansion analysis for delocalized systems. Int. J. Quantum. Chem. 1969, 3, 149167.

27. Purvis, G. D.; Bartlett, R. J. A full coupled-cluster singles and doubles model. The inclusion of disconnected triples. J. Chem. Phys. 1982, 76, 1910-1918.

28. Curtiss, L. A.; Raghavachari, K.; Pople, J. A. Gaussian-2 theory using reduced Møller-Plesset orders. J. Chem. Phys. 1993, 98, 1293-1298.

29. (a) Hegarty, D.; Robb, M. A. Application of unitary group methods for configuration interaction calculations. Mol. Phys. 1979, 38, 1795-1812. (b) Frisch, M.; Ragazos, I. N.; Robb, M. A.; Schlegel, H. B. An evaluation of three direct MC-SCF procedures. Chem. Phys. Lett. 1992, 189, 524-528.

30. Zhu, L.; Hase, W. L. Quantum chemistry program exchange; Indiana University: Bloomington, IN, 1994; Program no. QCPE 644.

31. Frank, A. J.; Sadilek, M.; Ferrier, J. G.; Tureček, F. Sulfur oxyacids and radicals in the gas phase. A variable-time neutralizationphotoexcitation-reionization mass spectrometric and ab initio/ RRKM study. J. Am. Chem. Soc. 1997, 119, 12343-12353.

32. NIST Standard reference database number 69; March, 2003; release; http://webbook.nist.gov/chemistry.

33. Bohme, D. K.; Mackay, G. I.; Schiff, H. I. Determination of proton affinities from the kinetics of proton transfer reactions. VII. The proton affinities of $\mathrm{O}_{2}, \mathrm{H} 2, \mathrm{Kr}, \mathrm{O}, \mathrm{N}_{2}, \mathrm{Xe}, \mathrm{CO}_{2}, \mathrm{CH}_{4}$ $\mathrm{N}_{2} \mathrm{O}$, and CO. J. Chem. Phys. 1980, 73, 4976-4986.

34. Harrison, A. G. Chemical Ionization Mass Spectrometry, 2nd ed.; CRC Press: Boca Raton, 1992; p 18.

35. Chen, X.; Syrstad, E. A.; Gerbaux, P.; Nguyen, M. T.; Tureček, F. Distonic isomers and tautomers of adenine cation radical in the gas phase and aqueous solution. J. Phys. Chem. A 2004, 108, 9283-9293.

36. Wolken, J. K.; Tureček, F. Direct observation of a hydrogen atom adduct to O-4 in uracil. Energetics and kinetics of uracil radicals. J. Phys. Chem. A 2001, 105, 8352-8360.

37. (a) Tureček, F.; Hanus̆, V. Stereoelectronic control of ion fragmentations. The loss of hydrogen from cyclic ethers during electron impact mass spectrometry. Tetrahedron 1983, 39, 1499-1506. (b) Tureček, F.; Panciř, J.; Stahl, D.; Gäumann, T. Stereoelectronic effects on the retro-Diels-Alder fragmentation of ionized bicyclo[4.3.0]nona-3,7-dienes. Org. Mass Spectrom. 1985, 20, 360-367. (c) Tureček, F. Stereoelectronic effects in mass spectrometry. Int. J. Mass Spectrom. Ion Processes 1991, 108, 137-164.

38. Nguyen, V. Q.; Tureček, F. Energy effects in collisional neutralization with organic molecules. J. Mass Spectrom. 1996, 31, 843-854.

39. Tureček, F. The use of kinetic isotope effects for the determination of internal energy distributions of isolated transient species in the gas phase. Int. J. Mass Spectrom. 2003, 227, 327-338. 
40. Hop, C. E. C. A.; Holmes, J. L. Fragmentation characteristics of the unstable $\left[\mathrm{CH}_{3} \mathrm{CO}\right]$ radicals generated by neutralization of $\left[\mathrm{CH}_{3} \mathrm{CO}\right]^{+}$cations. Int. J. Mass Spectrom. Ion Processes 1991, 104, 213-226.

41. (a) Tureček, F.; Gu, M.; Hop, C. E. C. A. Franck-Condon dominated chemistry. Formation and dissociations of tetrahydroxyphosphoranyl radicals following femtosecond reduction of their cations in the gas phase. J. Phys. Chem. 1995, 99, 2278-2291. (b) Nguyen, V. Q.; Shaffer, S. A.; Tureček, F.; Hop, C. E. C. A. Franck-Condon dominated chemistry. Dissociations of silicon-centered radicals prepared by femtosecond reduction of their cations in the gas phase. J. Phys. Chem. 1995, 99, 15454-15464.

42. Lifshitz, C. Time-resolved appearance energies, breakdown graphs, and mass spectra: The elusive kinetic shift. Mass Spectrom. Rev. 1982, 1, 309-348.

43. Hop, C. E. C. A.; Holmes, J. L. Neutralization-reionization mass spectrometry: Efficiency of the charge-exchange process. Org. Mass Spectrom. 1991, 26, 476-480.

44. Syrstad, E. A.; Vivekananda, S.; Tureček, F. Direct observation of a hydrogen atom adduct to $\mathrm{C}-5$ in uracil. A neutralizationreionization mass spectrometric and ab initio study. J. Phys. Chem. A 2001, 105, 8339-8351.

45. Syrstad, E. A.; Tureček, F. Toward a general mechanism of electroncapture dissociation. J. Am. Soc. Mass Spectrom. 2005, 16, 208-224.

46. Tureček, F.; Syrstad, E. A. Mechanism and energetics of intramolecular hydrogen transfer in amide and peptide radicals and cation-radicals. J. Am. Chem. Soc. 2003, 125, 3353-3369.

47. Nguyen, V. Q.; Tureček, F. Protonation sites in gaseous pyrrole and imidazole: A neutralization-reionization and ab initio study. J. Mass Spectrom. 1996, 31, 1173-1184.

48. Iavarone, A. T.; Paech, K.; Williams, E. R. Effects of charge state and cationizing agent on the electron capture dissociation of a peptide. Anal. Chem. 2004, 76, 2231-2238. 